Review

\title{
Overview of Bee Pollination and Its Economic Value for Crop Production
}

\author{
Shaden A. M. Khalifa ${ }^{1, *}$, Esraa H. Elshafiey ${ }^{2}$, Aya A. Shetaia ${ }^{2}$, Aida A. Abd El-Wahed ${ }^{3}{ }^{-}$, Ahmed F. Algethami ${ }^{4}$, \\ Syed G. Musharraf ${ }^{5}$, Mohamed F. AlAjmi ${ }^{6}$, Chao Zhao ${ }^{7}$ (D) Saad H. D. Masry ${ }^{8,9}$, Mohamed M. Abdel-Daim ${ }^{10} \mathbb{D}^{(}$, \\ Mohammed F. Halabi ${ }^{11}$, Guoyin Kai ${ }^{12}$, Yahya Al Naggar ${ }^{13,14}{ }^{\complement}$, Mokhtar Bishr ${ }^{15}$, Mohamed A. M. Diab ${ }^{16}$ \\ and Hesham R. El-Seedi ${ }^{2,17,18, *}$
}

Citation: Khalifa, S.A.M.; Elshafiey, E.H.; Shetaia, A.A.; El-Wahed, A.A.A.; Algethami, A.F.; Musharraf, S.G.; AlAjmi, M.F.; Zhao, C.; Masry, S.H.D.; Abdel-Daim, M.M.; et al. Overview of Bee Pollination and Its Economic Value for Crop Production. Insects 2021, 12, 688. https://doi.org/ $10.3390 /$ insects 12080688

Academic Editors: Michelle

T. Fountain, Ignazio Floris and Mariano Higes Pascual

Received: 16 April 2021

Accepted: 23 July 2021

Published: 31 July 2021

Publisher's Note: MDPI stays neutral with regard to jurisdictional claims in published maps and institutional affiliations.

Copyright: (c) 2021 by the authors. Licensee MDPI, Basel, Switzerland. This article is an open access article distributed under the terms and conditions of the Creative Commons Attribution (CC BY) license (https:// creativecommons.org/licenses/by/ $4.0 /)$
1 Department of Molecular Biosciences, The Wenner-Gren Institute, Stockholm University, S-10691 Stockholm, Sweden

2 Department of Chemistry, Faculty of Science, Menoufia University, Shebin El-Kom 32512, Egypt; esraaelshafiey8@gmail.com (E.H.E.); aya.shetaia@gmail.com (A.A.S.)

3 Agricultural Research Centre, Department of Bee Research, Plant Protection Research Institute, Giza 12627, Egypt; aidaabd.elwahed@arc.sci.eg

4 Alnahalaljwal Foundation Saudi Arabia, P.O. Box 617, Al Jumum 21926, Makkah, Saudi Arabia; ahmed@alnahalaljwal.com.sa

5 International Center for Chemical and Biological Sciences, H.E.J. Research Institute of Chemistry, University of Karachi, Karachi 75270, Pakistan; musharraf@iccs.edu

6 Department of Pharmacognosy, College of Pharmacy, King Saud University, Riyadh 11451, Saudi Arabia; malajmii@ksu.edu.sa

7 College of Food Science, Fujian Agriculture and Forestry University, Fuzhou 350002, China; zhchao@live.cn

8 Department of Plant Protection and Biomolecular Diagnosis, Arid Lands Cultivation Research Institute (ALCRI), City of Scientific Research and Technological Applications,

New Borg El-Arab City P.O. Box 21934, Egypt; saad.masry@adafsa.gov.ae

9 Abu Dhabi Agriculture and Food Safety Authority (ADAFSA), Al Ain 52150, United Arab Emirates

10 Pharmacology Department, Faculty of Veterinary Medicine, Suez Canal University, Ismailia 41522, Egypt; abdeldaim.m@vet.suez.edu.eg

11 Al-Rayan Research and Innovation Center, Al-Rayan Colleges, Medina 42541, Saudi Arabia; m.halabi@amc.edu.sa

12 Laboratory of Medicinal Plant Biotechnology, College of Pharmacy, Zhejiang Chinese Medical University, Hangzhou 310053, China; kaiguoyin@zcmu.edu.cn

13 General Zoology, Institute for Biology, Martin Luther University Halle-Wittenberg, Hoher Weg 8, 06120 Halle, Germany; yehia.elnagar@science.tanta.edu.eg

14 Zoology Department, Faculty of Science, Tanta University, Tanta 31527, Egypt

15 Arab Company for Pharmaceuticals and Medicinal Plants, (Mepaco-Medifood), El-Sharqiya 11361, Egypt; m-bishr@mepaco-pharma.net

16 EWG Company, Menoufia, Shebin El-Kom 32512, Egypt; Mmmdiab82@gmail.com

17 Pharmacognosy Group, Biomedical Centre, Department of Pharmaceutical Biosciences, Uppsala University, P.O. Box 591, SE 75124 Uppsala, Sweden

18 International Research Center for Food Nutrition and Safety, Jiangsu University, Zhenjiang 212013, China

* Correspondence: shaden.khalifa.2014@gmail.com (S.A.M.K.); hesham.el-seedi@farmbio.uu.se (H.R.E.-S.); Tel.: +46-700-10-11-13 (S.A.M.K.); +46-700-43-43-43 (H.R.E.-S.)

Simple Summary: There is a rising demand for food security in the face of threats posed by a growing human population. Bees as an insect play a crucial role in crop pollination alongside other animal pollinators such as bats, birds, beetles, moths, hoverflies, wasps, thrips, and butterflies and other vectors such as wind and water. Bees contribute to the global food supply via pollinating a wide range of crops, including fruits, vegetables, oilseeds, legumes, etc. The economic benefit of bees to food production per year was reported including the cash crops, i.e., coffee, cocoa, almond and soybean, compared to self-pollination. Bee pollination improves the quality and quantity of fruits, nuts, and oils. Bee colonies are faced with many challenges that influence their growth, reproduction, and sustainability, particularly climate change, pesticides, land use, and management strength, so it is important to highlight these factors for the sake of gainful pollination.

Abstract: Pollination plays a significant role in the agriculture sector and serves as a basic pillar for crop production. Plants depend on vectors to move pollen, which can include water, wind, and 
animal pollinators like bats, moths, hoverflies, birds, bees, butterflies, wasps, thrips, and beetles. Cultivated plants are typically pollinated by animals. Animal-based pollination contributes to $30 \%$ of global food production, and bee-pollinated crops contribute to approximately one-third of the total human dietary supply. Bees are considered significant pollinators due to their effectiveness and wide availability. Bee pollination provides excellent value to crop quality and quantity, improving global economic and dietary outcomes. This review highlights the role played by bee pollination, which influences the economy, and enlists the different types of bees and other insects associated with pollination.

Keywords: bees pollination; economic; crop production; bee visitation; challenges; impact

\section{Introduction}

Pollination plays a vital role in maintaining the natural balance of ecosystems and is the cornerstone of crop production, providing a link between agriculture and the cycle of life. Consequently, pollination has a role in the economic sector owing to the improvement of quality and quantity [1-3].

Pollination is defined as the process by which pollen moves from the male anthers to the female stigmata, either within the same flower (self-pollination) or between plants (cross-pollination) [4,5]. Pollinators are the key players of the crop yield process since plants completely rely on vectors to transfer their pollen in cross-pollination. For instance, incorporating both wild and managed bee species in a region could enhance cross-pollination [6]. Possible other vectors include water and wind, and animal pollinators involve bats, birds, butterflies, hoverflies, wasps, thrips, diptera, and other animals [6-9].

Animal pollinators contribute to the production of 87 global crops, including cocoa (Theobroma cacao), kiwi (Actinidia deliciosa var. deliciosa), passion fruit (Passiflora edulis), and watermelon (Citrullus lanatus) from 200 countries. Thirty percent of these crops participate in global economic food production. Global pollination's economic value averaged EUR 153 billion, which is worth $9.5 \%$ of the world's agricultural production of human food in 2005. The leading categories of insect-pollinated crops are vegetables and fruit, making around EUR 50 billion each, followed by edible petroleum crops, stimulants, nuts and spices. The one ton of crop production that is not dependent on insect pollination is valued at about EUR 151, compared to an average of EUR 761 for crops dependent on pollinators [10]. Pollination by insects is a key element in the production of a large number of agricultural products worldwide, including aromatic and medicinal plants such as black cumin (Nigella sativa linn), cumin (Cuminum cyminum linn) [11], anise (Pimpinella anisum linn) [12], sunflower (Helianthus spp.) [13], and coriander (Coriandrum sativum linn) [14]. Each season, honey bees, local bees, and flies pollinate 48 crops of the world's most valuable commodities, contributing significantly to the global economy. [15]. For instance, in the USA alone, pollination results in USD 16 billion annually with USD 12 billion attributable solely to the accessibility of honey bees [16,17].

The Western honey bee (Apis mellifera L.) is the main species responsible for bee pollination worldwide and meets, for instance, $34 \%$ of pollination service demands in the United Kingdom [2,18]. Although several other bee species also contribute to pollination, researchers have focused on only a limited number of these to date, particularly the bumble bee (Bombus spp.) [19,20]. In comparison to wild bees alone, Greenleaf and Kremen observed that interactions between wild bees and honey bees doubled pollination rates and enhanced the prevalence of hybrid sunflowers by five-fold [21].

This review aims to highlight the role of the bee in plant pollination and its impact on the economy. The factors influencing bee visitation of flowers and plants, in addition to a comparison of bees and other insect pollinators, are reported. 


\section{Effect of Bee Pollination on the Economy}

There is an ever-increasing demand for food security in the face of challenges such as climate change, land-use changes, habitat transformation, and the expanding human population. Proper pollination can improve the quantity and quality of fruits, nuts, oils, and other crops produced [22]. According to market prices, pollination by animals improves the global crop output by an additional USD 235-577 billion annually, with the greatest economic benefits having been seen in the Mediterranean, Southern and Eastern Asia, and Europe [23]. However, greater production also leads to an increased demand for pollination services [24]. Around the world, $5-8 \%$ of crop production would be lost without animal pollination [25], and pollination also provides many services to ecosystems, such as enhancing biodiversity and increasing food production without threatening the environment [26].

Bees are the main pollinators of plants. According to Gallai et al., insect pollination provided EUR 153 billion, representing 9.5\% of the total economic value of agricultural production used directly for human food [10]. Consequently, countries that grow cash crops such as coffee (Coffea spp.), cocoa, almond (Prunus dulcis ((Mill.)), and soybeans (Glycine $\max \mathrm{L}$.) have a much greater reliance on pollination in agriculture at a large scale [27-29]. Scientists have used several methods to estimate the annual benefit of certain ecological costs incurred by native insects in the USA, which have been shown to amount to more than USD 57 billion, USD 3.07 billion of which is a result of bee pollination [30]. The pollination services of non-apis pollinators were valued at USD 3.44 billion, but honey bees contributed approximately USD 11.68 billion by 2009 in USA [16]. Honey bees are responsible for pollinating over 100 commercial crops in North America [3]. Both honey bees and wild bees are also economically important for sunflower seed production, which is an uprising industry estimated at approximately USD 10.4 million annually [21].

Bee pollination also increases the yield of crops cultivated in farmland. For instance, in sub-Saharan Africa, which is considered the main producer of cotton $[29,31]$, bee pollination increases the cotton yield to $62 \%$ compared with an estimated $37 \%$ without bee pollination [32]. In addition, economic returns from bee pollination have been recorded in smallholder farming systems in Kakamega (western Kenya), where several crops benefit from pollination, including green gram (Vigna radiata), beans, cowpea (Vigna unguiculata L. Walp), sunflower, tomato (Solanum lycopersicum linn), bambara groundnut (Voandzeia subterranean L.), passion fruit, and capsicum, with pollination dramatically improving the production rate and being responsible for almost $40 \%$ of the annual crop production [33].

The estimated annual value of pollination services rendered by bees in Brazil's protected areas in 2016 was approximately USD 564,000 in the north (Serra da Bocaina, Pará) and USD 246,000 in the southeastern region (Mata do Jambreiro) [34]. Of the 36 crops produced in the state of Pará, $20(55 \%)$ are dependent on animal pollinators, and the overall value of pollination services was USD 983.2 million in 2016, equating to $33 \%$ of the total value of crop production (USD 2.95 billion). Four groups represented for $96 \%$ of Pará's pollination service value including; cocoa (USD 187.6 million), Acaí palm (USD 635.6 million), watermelon (USD 26.1 million), and soybean (USD 98.4 million) [35]. In the USA, wild bees and honey bees have produced comparable quantities of pollination for most crops, including in agriculturally-intensive areas. The annual production value of wild pollinators for seven crops is over USD 1.5 billion. The value of wild pollinators is estimated to be the largest in apples, with a value of USD 1.06 billion while the approximate values of watermelon (USD 146 million), blueberry (USD 50 million), sweet cherry (USD 145 million), art cherry (USD 32 million), and pumpkin (USD 101 million) are evidentially high. The economic value of honey bees on yield across these crops is about USD 6.4 billion [36].

\section{Role of Bee Pollination in Crop Production (Quality and Quantity)}

The number of visits and the aggregate effects of various bee species influence not only the quantity of crops produced but also their quality, which is important mainly from an economic perspective [37]. Plant pollination by more than one bee species, including 
honey bees, carpenter bees, stingless bees, bumble bees, long-tongued bee, feral bees, social bees, and solitary bees, results in a better pollination/vegetation process, as shown in Table 1.

\subsection{Honey Bees}

Western honey bee have been widely used as pollinators since the application of pollination services began, and are the primary managed species worldwide for both honey production and crop pollination [38]. Indeed, the Western honey bee ranks as the single most popular species of pollinator for crops globally [39], and is the most effective crop visitor worldwide, contributing approximately $13 \%$ of floral visits to $5 \%$ of plant species across all plant networks [40]. However, there are at least eight other honey bee species in the genus Apis, such as A. florea Fabr., A. cerana Fabr., A. andreniformis, and A. dorsata Fabr [41]. In 2009, it was estimated that honey bees contributed USD 11.68 billion to agriculture in the USA [16].

Honey bees are considered significant pollinators due to their effectiveness and wide availability [16]. The mutualistic relationship between plants and honey bees results from the exchange of nectar and pollen. Bees play a vital role in the pollination of plants [40], and plants secrete a rich liquid sugar similar to nectar from their glands to attract pollinators to their flowers so that the pollen can adhere to bee-collected pollen grains [42]. Researchers have found that honey bees (A. mellifera L.) appear to prefer crops rich with nectar and pollen in order to store large quantities of food, thus sustaining the colony growth and improving foraging performance [43,44].

Many countries have used honey bees and achieved great results in terms of the quality and quantity of crops, as shown in Table 1. In the USA, the pollination activity of honey bees is well recognized for three species of crops: cucumber (Cucumis sativus Linn), for which there has been a 10\% increase in yield and the number of colonies has increased from 40,000 to 45,000; cranberry (Vaccinium oxycoccos Linn), which experienced an increase in yield from 3.7 million in 1989 to 5.4 million in 1998 [45], and pear (Pyrus communis Linn), which exhibited a $7 \%$ increase in fruit size and a net income increase of $\$ 400$ per hectare [46]. In India, the use of honey bees as pollinators improved the fruit quality of guava (Psidium guajava Linn), as well as the fruit length and girth of coconut (Cocos nucifera Linn) and citrus (Citrus spp.) compared with the controls [47,48]. In Egypt, honey bees have significantly improved the seed set percentage and seed yield in onion (Allium cepa Linn) crops compared with other insects [49]. Furthermore, in Burkina Faso, the production of sesame (Sesamum indicum Linn) seeds tripled after using honey bees as pollinators [32].

The pollination of oilseed rape (Brassica napus Linn), buckwheat (Fagopyrum esculentum Moench), and strawberry (Fragaria $\times$ ananassa (Duchesne ex Weston) Duchesne ex Rozier) have clearly been dominated by honey bees, which have improved their quality and yield [50]. Similarly, black cumin flowers are attractive to a range of pollinators, such as Hemiptera (true bugs), Coleoptera (beetles), Diptera (flies), and Hymenoptera (bees) [51]. However, honey bees are the most abundant pollinators affecting its productivity and quality [11], with their pollination activity increasing the number of seeds and affecting the total yield, which has led to the recommendation that beekeepers place bee colonies near black cumin fields for better pollination [52].

The yield of anise also significantly relies on pollinator activity. One study showed that honey bees exhibited a daily peak in anise pollination activity between 12 noon and 2 p.m., and increased the yield above levels seen with insect exclusion, though levels were below those obtained with open pollination [12]. Honey bees and six species of Andrenidae are the main pollinators of coriander, with $63 \%$ of honey bee visits and $100 \%$ of the visits by three species of Andrenidae resulting in pollinating activity [53].

For the apple (Malus domestica Borkh), increased flower visitation rates by high-quality honey bee colonies increased fruit set by $15 \%$, as well as the fruit sugar content and seed set compared with visits by conventional colonies, resulting in the farmer's profits increasing 
by $70 \%$. Pollination by high-quality colonies also increased fruit weight by approximately $20 \%$ [54]. In the fruit of cape gooseberry (Physalis peruviana Linn), western honey bees' pollination improved the equatorial diameter by a mean of $13.3 \%$, fruit mass by $30.3 \%$, seed variety by $7 \%$, and seed mass by $8.4 \%$ compared with self-pollination [55], while the use of honey bees for almond pollination increased fruit set by $60 \%$ compared with bee-remote trees, which translated into a $20 \%$ increase in yield [29]. Observations of blueberry (Vaccinium corymbosum Linn) pollination in the presence of wild bees (Bombus spp., Halictids bees, Andrenids bees, and Xylocopa virginica) and controlled honey bees in small isolated and large fields in Michigan, USA, showed that wild bees were the primary pollinators in the small fields, accounting for $58 \%$ of flower visits, whereas honey bees were the main pollinators in the large fields, accounting for $97 \%$ of visits. Furthermore, it was found that flowers in the large fields were visited by four times as many bees as flowers in the small fields. The weight of the fruit was affected by the level of bee pollination and the abundance of bees, and the weight of berries was twice as high in the large fields compared with the small fields [56].

\subsection{Bumble Bees}

Bumble bees (Apidae: Bombini) are vital pollinators for agricultural and wild plants worldwide, and their pollination supports food security [57]. Five species of bumble bees are generally used for pollination of commercial crops: Bombus terrestris Linn (in Europe, North Africa, Asia, and Australasia), B. occidentalis Greene (in western North America), B. ignitus and B. lucorum Linn (in East Asia), and B. impatiens Cresson (in North America) [58].

The strong adaptation to different climates and habitats of bumble bees explains their ability to continue foraging even in high and low temperatures [59]. Bumble bees have contributed to the crop pollination via increasing the yield and enhancing the quality of fruits [60]. Indeed, fruit growers gain many benefits from pollination by bumble bees, which are good pollinators of several crops, such as kiwifruit (Actinidia Deliciosa) [61], sweet pepper (Capsicum annum Linn) [62,63], and red clover (Trifolium pretense Linn) (Table 1) [19].

Bumble bees are important pollinators of a diverse range of crops, including buzzpollinated crops, such as blueberry and tomato, as well as both large-flower and smallflower crops, giving them the potential to be sufficient pollinators in open fields and greenhouses $[64,65]$. It has also been shown that buzz pollination by Bombus haemorrhoidalis Smith in India leads to bigger, longer, heavier, and healthier fruits, especially in kiwi fruit [61].

Pollination by bumble bees enhances the quality and quantity of tomato fruit, including the number of fruit per cluster, the number of fruit per plant, fruit length, fruit freshness, fruit breadth, and fruit yield (Table 1) [65]. In addition, pollination of sweet pepper by bumble bees results in a larger number of pollen grains and a higher level of seed set on the fruit than self-pollination, such that flowers visited by bumble bees produce larger and heavier fruit than non-visited flowers [63]. Finally, bumble bees have provided maximum pollination services to hybrid leek (Allium porrum Linn), resulting in a $25 \%$ increase in plant quality, which has influenced the plant quality and crop price value by an estimated USD 18,007 and USD 17,174 hectare, respectively [60]. In some cases, wild pollinators give better pollination than honey bees, as seen in apple crops pollinated by bumble bees, because all wild bee species are able to hold and deposit more apple pollen than honey bees [66].

\subsection{Stingless Bees}

Stingless bees (Apidae: Meliponini) are common floral visitors in tropical and subtropical areas around the world. They exhibit greater dietary diversity and intensity in their foraging behavior than honey bees and so are likely to influence the future development of pollination solutions that are best suited to the needs of particular crops and habitats [67].

Stingless bees are a large, diverse group of eusocial bees, making them good candidate pollinators. They vary widely in their body size, being described as small- to medium-sized, and have vestigial stings [67]. Some species tend to be large and smooth, with long hairs 
that help to bring pollen and other products to the colony [68]. The physiology of stingless bees is suited to flower pollination [69] because they have suitable structures for collecting pollen, nectar, and an absence of stinging behavior, making them easier to handle than the majority of honey bees. Some stingless bees, such as those in the genus Melipona, exhibit vibration behavior to extract the pollen, which is needed in crops with poricidal anthers, such as tomato and pepper [70].

The neotropical stingless bee Melipona quadrifasciata Lepeletier is used to pollinate greenhouse tomatoes, and has improved the production of fruit with lower levels of mechanical injury [71]. Stingless bees also play a prominent role in the pollination of greenhouse cucumber crops, improving both the fruit weight and yield [72]. The pollination of cucumbers by the stingless bee Heterotrigona itama and manual cross-pollination improved crop quantity and fruit quality, allowing heavier, longer, and wider fruit to be produced [73]. Similarly, the pollination of rockmelon (Cucumis melo var. reticulatus) by stingless bees and manual cross-pollination had a positive effect on fruit set and the number of seeds per fruit compared with self-pollination [74], and the pollination of strawberries in greenhouses by stingless bees increased the quality and commercial value of the fruit compared with a control group [75]. Furthermore, the pollination of eggplant (Solanum melongena Linn) by Melipona fasciculata Smith in greenhouses increased fruit set by $29.5 \%$ and increased fruit quality (measured as fruit weight) compared with self-pollination [76].

\subsection{Carpenter Bees}

Large carpenter bees are a group of bees that occur in tropical and subtropical areas and belong to the genus Xylocopa in the tribe Xylocopini (Apidae: Xylocopinae) [77]. Compared with other non-Apis bees, carpenter bees have numerous advantages in crop pollination, as they feed on a broad range of plant species during their long activity seasons. They also have the ability to buzz-pollinate flowers, making them even more diverse crop pollinators [78]. However, there is a great need for a sufficient breeding program to be developed that involves the selection of genotypes, controlled mating, and nest foundation [79].

Carpenter bees are known for their ability to make their nests in tunnels in hard wood, logs, stumps, or the dead branches of trees [80]. In India, carpenter bees are active throughout the year and forage on a variety of flowers during the day and sometimes even work through moonlit nights. It has been noticed that flowers visited by carpenter bees produce nectar that is odoriferous, so it is possible that these bees use this odor as a cue to visit the correct flowers [81].

The use of carpenter bees for pollination services is necessary to guarantee adequate pollination for several crops, including passion fruit (Passiflora edulis $\mathrm{f}$. flavicarpa), cucurbits, and other vegetables and fruits, as observed in the Philippines, Brazil, USA, and Malaysia $[82,83]$. Yellow passion fruit is satisfactorily pollinated when the flowers are only visited by native bees, especially carpenter bees [84]. Furthermore, when native carpenter bees (Xylocopa (Lestis)) were used as an alternative to bumble bees for tomato pollination in a greenhouse, the females visited and buzz-pollinated the flowers and the resulting fruit were heavier and contained more seeds than those that were not pollinated by these bees [85]. The carpenter bee Xylocopa pubescens Spinola is also used to pollinate greenhousegrown honeydew melons (Cucumis melo Inodorus Group), as it was noticed that while this species had shorter visit durations per flower than the honey bee, pollination by both bees resulted in a similar fruit mass and seed numbers, and X. pubescens pollination increased fruit set three-fold compared with honey bee pollination [86].

\subsection{Solitary Bees}

Solitary bees comprise the majority of bee species in the world. Solitary bee species account for $85 \%$ of all bee species [87].The majority of solitary bees are polylectic (i.e., collect pollen from numerous plant species), while a smaller number are oligolectic (use a narrow range of plants) and very few are monolithic (use only a single plant species). In 
recent decades, there has been a decline in monolithic and oligolectic species in Britain [88]. Solitary bees play a major role in pollination, and it has been demonstrated that wild bees contribute USD 3251/hectare for their pollination services worldwide, seven out of ten of which are solitary [89]. Solitary bees are more effective pollinators than honey bees for some crops that depend on pollinators for their reproduction, such as apple. Indeed, in the United Kingdom, the economic gains of using solitary bees for apple production were estimated to be $€ 51.4$ million compared to honey bees of $€ 21.4$ million [90].

Table 1. The impact of bee pollination on crop quality and productivity in various countries.

\begin{tabular}{|c|c|c|c|c|}
\hline Crop (Species) & Bee Pollinator & Impact on Crop Yield & Country & Reference \\
\hline \multicolumn{5}{|c|}{ Fruits } \\
\hline \multirow{6}{*}{ Apple (Malus domestica L.) } & Honey bees (Apis mellifera L.) & $\begin{array}{l}\text { Enhancing fruit production with high yield and } \\
\text { quality (fruit size and number of seeds). }\end{array}$ & Pakistan & [91] \\
\hline & $\begin{array}{l}\text { Wild bees and honeybees } \\
\qquad \text { (A. mellifera })\end{array}$ & $\begin{array}{l}\text { Seed number increased with bee abundance which } \\
\text { consequently increased fruit quality. }\end{array}$ & China & [92] \\
\hline & $\begin{array}{l}\text { Stingless bees (Melipona } \\
\text { quadrifasciata anthidioides } \\
\text { Lepeletier) Africanised } \\
\text { honeybee }(A . \text { mellifera })\end{array}$ & $\begin{array}{l}\text { Both stingless bees ( } 12 \text { hives / hectare) and } \\
\text { Africanized honeybees ( } 7 \text { hives / hectare) provided } \\
\text { higher seed and fruit production than } \\
\text { supplementation with honeybees alone. }\end{array}$ & Brazil & [93] \\
\hline & Honey bee (A. mellifera) & $\begin{array}{l}\text { Increased fruit set by } 15 \% \text {, seed set and content of } \\
\text { fruit sugar, and farmer's profits by } 70 \% \text {. }\end{array}$ & Argentina & [54] \\
\hline & $\begin{array}{l}\text { Bumble bees (B. impatiens) } \\
\text { and honey bee (A. mellifera) }\end{array}$ & $\begin{array}{l}\text { The quantity and quality of fruits produced from } \\
\text { pollination from both species were equivalent. }\end{array}$ & Canada & [66] \\
\hline & Wild bees & Fruit set increased & USA & [94] \\
\hline \multirow{2}{*}{ Coconut (Cocos nucifera L.) } & Honey bees (A. mellifera) & Increased fruit set & Mexico & [48] \\
\hline & Honey bees (A. mellifera) & Effective pollinators compared to wasp & Jamaica & [95] \\
\hline $\begin{array}{l}\text { Watermelon } \\
\text { (Citrullus lanatus Thunb.) }\end{array}$ & Honey bees (A. mellifera) & $\begin{array}{l}\text { Fruit set, fruit numbers and weights per plot } \\
\text { increased linearly as number of honey } \\
\text { bees visits increased. }\end{array}$ & USA & [96] \\
\hline Tart cherry (Prunus cerasus L.) & Osmia lignaria solitary bee & $\begin{array}{l}\text { Cherry weight increased by } 2.8 \% \\
\text { compared to the control. }\end{array}$ & Utah & {$[97]$} \\
\hline $\begin{array}{l}\text { Cape gooseberry (Physalis } \\
\text { peruviana L.) }\end{array}$ & Honey bees (A. mellifera) & $\begin{array}{c}\text { Improvement of fruit mass by } 30.3 \% \text {, equatorial } \\
\text { diameter by } 13.3 \% \text {, seed variety by } 7 \% \text {, and } \\
\text { seed mass by } 8.4 \% \text {. }\end{array}$ & Colombia & [55] \\
\hline $\begin{array}{l}\text { Sweet cherry } \\
\text { (Prunus avium L.) }\end{array}$ & Wild bees and honey bees & $\begin{array}{l}\text { Fruit set was enhanced compared } \\
\text { to open pollination. }\end{array}$ & Germany & [98] \\
\hline \multirow{2}{*}{$\begin{array}{l}\text { Almond (Prunus dulcis (Mill.) } \\
\text { D.A.Webb) }\end{array}$} & Honey bees (A. mellifera) & $\begin{array}{l}\text { Increased fruit set by } 60 \% \text { and kernel yield by } 20 \% \\
\text { compared to self-pollination. }\end{array}$ & USA & [29] \\
\hline & Solitary Bee (O. cornuta) & $\begin{array}{l}\text { Increased fruit production was parallel with } \\
\text { increased visits by O. cornuta. }\end{array}$ & Spain & [99] \\
\hline $\begin{array}{c}\text { Avocado } \\
\text { (Persea americana Mill.) }\end{array}$ & Honey bees (A. mellifera) & $\begin{array}{l}\text { High pollination efficiency for fruit set, increased } \\
\text { the production, and improved the } \\
\text { weight of the fruit. }\end{array}$ & In Central America & [100] \\
\hline \multirow{2}{*}{$\begin{array}{l}\text { Passion fruit (Passiflora edulis } \\
\text { Sims. f. flavicarpa Deg) }\end{array}$} & $\begin{array}{l}\text { Honey bees (A. mellifera), and } \\
\text { carpenter bees (Xylocopa spp.) }\end{array}$ & $\begin{array}{l}\text { The diversity of bee species affected the fruit set } \\
\text { and fruit quality and led to a higher } \\
\text { reproductive efficiency. }\end{array}$ & Australia and Philippins & {$[82,83]$} \\
\hline & $\begin{array}{l}\text { Native Brazilian bees } \\
\text { (Xylocopa spp.) }\end{array}$ & $\begin{array}{l}\text { Production costs lowered by } 58 \% \text {. } \\
\text { Average production was } 7000 \mathrm{~kg} / \text { hectare/year. }\end{array}$ & Brazil & [101] \\
\hline Citrus (Citrus sinensis L.) & Honey bees (A. mellifera) & $\begin{array}{l}\text { Lead to heavier fruit with less acid content and } \\
\text { fewer seeds per bud. }\end{array}$ & Brazil & [102] \\
\hline Mango (Mangifera indica L.) & Honey bees (A. cerana) & $\begin{array}{c}\text { Fruit setting was } 42.29 \% \text { compared to open } \\
\text { pollination } 33.36 \% \text {. }\end{array}$ & India & [103] \\
\hline Guava (Psidium guajava L.) & Honey bees (A. mellifera) & $\begin{array}{c}\text { Increased fruit set; improved the quality of fruit } \\
\text { length and girth. }\end{array}$ & India & {$[47]$} \\
\hline \multirow[t]{3}{*}{$\begin{array}{l}\text { Strawberry }(\text { Fragaria } \times \\
\text { ananassa DUCH) }\end{array}$} & Osmia bicornis $\mathrm{L}$. & $\begin{array}{c}\text { Increased commercial value by } 54.3 \% \text { compared } \\
\text { with self-pollination and by } 38.6 \% \text { compared with } \\
\text { wind pollination. Number of fertilized achenes } \\
\text { increased, and improved post-harvest quality } \\
\text { occurred (more intensive red colour and lower } \\
\text { sugar acid ratios). }\end{array}$ & Germany & [104] \\
\hline & Bees & $\begin{array}{l}\text { Quantity and quality improved. } \\
\text { Yield increased } 20 \% \text {. }\end{array}$ & Germany & {$[50]$} \\
\hline & $\begin{array}{l}\text { European orchard bee } \\
\text { (Osmia cornuta Latr) }\end{array}$ & Fruit weight was higher than the control treatment. & Germany & [105] \\
\hline
\end{tabular}


Table 1. Cont.

\begin{tabular}{|c|c|c|c|c|}
\hline Crop (Species) & Bee Pollinator & Impact on Crop Yield & Country & Reference \\
\hline \multirow[b]{2}{*}{ Kiwifruit (Actinidia Deliciosa) } & Honey bees (A. mellifera) & Increased fruit set and yield. & Australia & [106] \\
\hline & $\begin{array}{l}\text { Bumble bee (Bombus } \\
\text { haemorrhoidalis Smith) }\end{array}$ & $\begin{array}{l}\text { Higher fruit breadth, longer fruits, heavier fruits, } \\
\text { higher healthy fruits, and higher fruit set. }\end{array}$ & India & [61] \\
\hline Pear (Pyrus communis L.) & Honey bees (A. mellifera) & $\begin{array}{l}\text { Fruit size increased by } 7 \% \text { and lead to USD } 400 \text { per } \\
\text { hectare net increase in income. }\end{array}$ & USA & [46] \\
\hline $\begin{array}{l}\text { Cranberries (Vaccinium } \\
\text { oxycoccos L.) }\end{array}$ & Honey bees (A. mellifera) & $\begin{array}{l}\text { Production increased from } 3.7 \text { million in } 1989 \text { to } \\
5.4 \text { million in } 1998 .\end{array}$ & USA & {$[45]$} \\
\hline \multicolumn{5}{|c|}{ Vegetables } \\
\hline \multirow{2}{*}{$\begin{array}{c}\text { Cucumbers } \\
\text { (Cucumis sativus L.) }\end{array}$} & Honey bees (A. mellifera) & $10 \%$ increase in production. & USA & [45] \\
\hline & $\begin{array}{c}\text { Stingless bee } \\
\text { (Heterotrigona itama) }\end{array}$ & Lead to larger, heavier, and longer cucumbers. & Terengganu & [73] \\
\hline \multirow[b]{2}{*}{$\begin{array}{l}\text { Sweet pepper (Capsicum } \\
\text { annuum L.) }\end{array}$} & $\begin{array}{c}\text { Bumble bee } \\
\text { (Bombus impatiens } \mathrm{Cr} \text { ) }\end{array}$ & $\begin{array}{c}\text { Increased fruit weight, width, and volume. } \\
\text { Increased seed weight and reduced } \\
\text { harvesting time. }\end{array}$ & Canada & [62] \\
\hline & $\begin{array}{l}\text { Bumble bees } \\
\text { (Bombus terrestris L.) }\end{array}$ & $\begin{array}{l}\text { Increased yields, fruit weight, and quality of seed, } \\
\text { and fruits under unheated greenhouse conditions. } \\
\text { Seed set was } 49.8 \% \text { compared to } 27.5 \% \text { of the } \\
\text { control (self-pollination) treatment. }\end{array}$ & Spain & {$[63]$} \\
\hline \multirow[b]{2}{*}{$\begin{array}{l}\text { Tomatoes (Solanum } \\
\text { lycopersicum L.) }\end{array}$} & $\begin{array}{l}\text { Bumble bee (Anthophora } \\
\text { urbana Cresson and Bombus } \\
\text { vosnesenskii Radoszkowski) }\end{array}$ & $\begin{array}{l}\text { Lead to higher yield and improved the } \\
\text { quality of fruits. }\end{array}$ & USA & [107] \\
\hline & $\begin{array}{c}\text { Bees (Exomalopsis analis } \\
\text { Spinola, Centris tarsata Smith, } \\
\text { Bombus morio Swederus, } \\
\text { Eulaema nigrita Lepeletier and } \\
\text { Epicharis sp.) }\end{array}$ & Increased fruit production and quality. & Brazil & [108] \\
\hline \multicolumn{5}{|c|}{ Aromatic and medicinal plants } \\
\hline Anise (Pimpinella anisum L.) & Honey bees (A. mellifera) & $\begin{array}{l}\text { Increasing seed yield/feddan to } 781.55 \mathrm{~kg} \\
\text { compared to } 300.24 \mathrm{Kg} \text { for control group } \\
\text { (insect exclusion). }\end{array}$ & Egypt & [12] \\
\hline Black Seed (Nigella sativa L.) & Honeybee (A. mellifera) & $\begin{array}{l}\text { Increased yield and seed setting but no effect on } \\
\text { the weight of the seed produced. }\end{array}$ & Pakistan & [109] \\
\hline $\begin{array}{l}\text { Cumin } \\
\text { (Cuminum cyminum L.) }\end{array}$ & $\begin{array}{l}\text { Apis florea F., A. mellifera and } \\
\text { A. dorsata }\end{array}$ & $\begin{array}{l}\text { Enhanced yield by } 40.03 \% \text { compared to } 41.37 \% \text { for } \\
\text { open pollination. }\end{array}$ & India & [11] \\
\hline \multirow{3}{*}{$\begin{array}{l}\text { Sunflowers (Helianthus } \\
\text { annuus L.) }\end{array}$} & $\begin{array}{l}\text { Wild bees and honey bees } \\
\qquad(\text { A. mellifera })\end{array}$ & $\begin{array}{l}\text { Interactions between wild and honey bees } \\
\text { increased the efficiency of pollination up to 5-fold } \\
\text { compared to honey bees only. }\end{array}$ & USA & [21] \\
\hline & $\begin{array}{l}\text { Africanized honey bees } \\
\quad(\text { A. mellifera })\end{array}$ & $\begin{array}{l}\text { The average yield of seeds was } 43 \% \text { higher } \\
\text { compared to the control. }\end{array}$ & Brazil & [13] \\
\hline & Honey bees (Apis mellifera L.) & $\begin{array}{l}\text { Played a significant role in pollination compared to } \\
\text { moths and wind. }\end{array}$ & Central Darling Downs & [110] \\
\hline $\begin{array}{l}\text { Coriander (Coriandrum } \\
\text { sativum Linnaeus.) }\end{array}$ & Apis cerana Fabricius & $\begin{array}{c}\text { The seed set was significantly higher by } 69.51 \% \\
\text { compared to } 54.89 \% \text { in the control group. The } \\
\text { yield was } 14.57 \mathrm{q} / \text { hectare vs } 11.66 \mathrm{q} / \text { hectare in the } \\
\text { control group. }\end{array}$ & India & [14] \\
\hline \multicolumn{5}{|c|}{ Other plants } \\
\hline \multirow[b]{2}{*}{ Cotton Gossypium hirsutum L.) } & Honey bees (A. mellifera) & $\begin{array}{l}\text { Increased production by more than } 12 \% \text { for fiber } \\
\text { weight and over } 17 \% \text { for seed number. }\end{array}$ & Brazil & [111] \\
\hline & Honeybees and wild bees & $\begin{array}{l}\text { Significantly increased yield quantity and quality } \\
\text { by an average of } 62 \% \text {. The average yield was } \\
953.91 \mathrm{~kg} / \text { hectare. }\end{array}$ & West Africa & [32] \\
\hline $\begin{array}{c}\text { Pumpkins } \\
\text { (Cucurbita maxima L.) }\end{array}$ & Honey bees (A. mellifera) & $\begin{array}{l}\text { Fruit set, fruit size, weight, and number of seeds } \\
\text { increased linearly with the number of visits. }\end{array}$ & Brazil & [112] \\
\hline \multirow[t]{2}{*}{ Soyabean (Glycine max L.) } & Honey bees (A. mellifera) & $\begin{array}{l}\text { Yield increase was associated with an increase of } \\
\text { the seed number. }\end{array}$ & Argentina & [113] \\
\hline & Honey bees (A. mellifera) & Increased yield by $18.09 \%$. & Brazil & [114] \\
\hline Sesame (Sesamum indicum L.) & $\begin{array}{l}\text { Honeybees (A. mellifera) and } \\
\text { wild bees }\end{array}$ & $\begin{array}{l}\text { The mean yield of seed was } 202.20 \mathrm{~kg} / \text { hectare. } \\
\text { The exclusion of pollinators caused an average } \\
\text { yield gap of } 59 \% \text {. }\end{array}$ & West Africa & [32] \\
\hline
\end{tabular}


Table 1. Cont.

\begin{tabular}{|c|c|c|c|c|}
\hline Crop (Species) & Bee Pollinator & Impact on Crop Yield & Country & Reference \\
\hline C. canephora $\mathrm{L}$ & Apis dorsata $\mathrm{F}$. & $\begin{array}{l}\text { Bees increased fruit production of coffee by } 50 \% \\
\text { more than wind. }\end{array}$ & South India & [115] \\
\hline $\begin{array}{c}\text { Cowpea } \\
\text { (Vigna unguiculata L. Walp) }\end{array}$ & Honey bees and bumble bees & NR & Nigeria & [116] \\
\hline $\begin{array}{l}\text { Red clover seed (Trifolium } \\
\text { pratense L.) legume }\end{array}$ & Bumble bee (B. vosnesenskii) & High yield and most production of seeds. & USA & [19] \\
\hline $\begin{array}{l}\text { Pineland golden trumpet } \\
\text { (Angadenia berteroi } \\
\text { (A.DC.) Miers) }\end{array}$ & $\begin{array}{l}\text { Long-tongued bee (Megachile } \\
\text { georgica Cresson and } \\
\text { Melissodes } \\
\text { communis communis) }\end{array}$ & NR & USA & [117] \\
\hline \multirow[b]{2}{*}{ Mustard (Brassica juncea L.) } & Honey bees (A. mellifera) & $\begin{array}{l}\text { Increased fruit set, viability of seed, seed yield, and } \\
\text { oil nutrient contents in the seed. }\end{array}$ & India & [118] \\
\hline & Honey bees (A. cerana) & $\begin{array}{c}\text { Increased siliqua/panicle by } 20.8 \% \text {, seeds / silique } \\
\text { by } 9.4 \% \text {, and seed yield by } 17.1 \% \text { compared to } \\
\text { open pollination. }\end{array}$ & India & [119] \\
\hline $\begin{array}{l}\text { Green grams (Vigna radiate L.) } \\
\text { and Bambara groundnut } \\
\text { (Voandzeia subterranean L.) }\end{array}$ & Feral bees & Enhanced yield and improved the quality of crops. & Kenya & [33] \\
\hline Coffee (Coffea arabica L.) & Solitary bees and social bees & Significantly increased fruit set. & Indonesia & [120] \\
\hline $\begin{array}{c}\text { Acai palm } \\
\text { (Euterpe oleracea Martius) }\end{array}$ & $\begin{array}{c}\text { Stingless bee } \\
\text { (Scaptotrigona aff. postica) }\end{array}$ & $\begin{array}{l}\text { Increased the production reach to } 2.5 \text { times. } \\
\text { The increase was evident as per the number of } \\
\text { fruits per bunch and fruit size. }\end{array}$ & Brazil & [121] \\
\hline \multirow{3}{*}{$\begin{array}{c}\text { Oilseed rape } \\
\text { (Brassica napus L.) }\end{array}$} & $\begin{array}{l}\text { Solitary mason bee } \\
\text { (Osmia rufa L.) }\end{array}$ & $\begin{array}{l}\text { Increased fruit set, yield, and the number of seeds } \\
\text { per pod by bee density. }\end{array}$ & Germany & [122] \\
\hline & Honey bees (A. mellifera) & Increased oil and decreasing chlorophyll content. & Sweden & [50] \\
\hline & $\begin{array}{l}\text { Honey bees ( } A \text {. mellifera), and } \\
\text { wild bees (Lasioglossum spp.). }\end{array}$ & Average yield was increased up to $37.5 \%$. & France & [123] \\
\hline
\end{tabular}

NR: Not reported.

\section{Bee Visitation}

Pollination is carried out by bees and other insects for a variety of plants. Because pollination is so important to plants, they adapt to be more appealing to pollinators $[124,125]$. Plants possess several means to attract bees, including flower color [126,127], flower motion as in the case of bumble bees [128], the type of plant cells (e.g., conical epidermal cells) as in bumble bees [129], visual and olfactory cues as in honey bees and apple pollination [130] and the production of nectar and pollen grains [131,132], as shown in Figure 1. Thus, plants play an important role in influencing the visitation rate of their pollinators [133].

One of the most important properties of plants that attracts bees is the color of the flowers $[134,135]$. Bees have a trichromatic visual system that is sensitive to green, ultraviolet, white, and blue wavelengths, allowing them to see numerous colors. Bees often visit blue or purple flowers but mostly prefer blue flowers [136,137]. By contrast, bees are less attracted to red flowers, though they will sometimes visit red flowers that reflect ultraviolet light [138].

The motion of flowers is also crucial for enhancing attractiveness to bees, as this is integral to their three-dimensional vision. The relative motion of the flowers increases the number of opposing stimuli on the bee's eye. Conical epidermal cells have multiple functions, such as promoting the perception of flower color and reducing the wettability of the petal, which increases the effectiveness of the pollination process. Consequently, bees usually prefer to visit conical-celled Petunia flowers, particularly those that are most attractive with motion $[139,140]$. Indeed, higher numbers of bees occur on the moving portion of a flower bed due to their positive response to optical stimulation [139]. In addition, floral volatile compounds affect the orientation of bees [141], as well as pollen collection and behavior in bumble bees [142]. Flower size has a special function for attracting pollinators [141]; bumble bees (Bombus diversus Smith) prefer large floral displays [143]. 


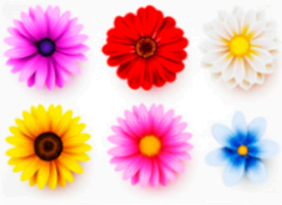

Flower color

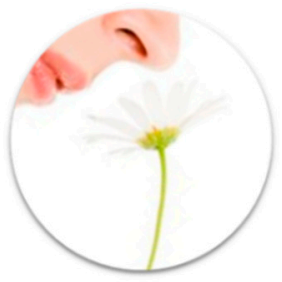

Flower odor

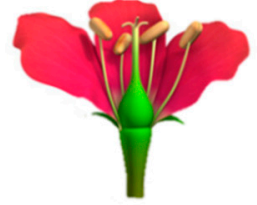

Flower structure and shape

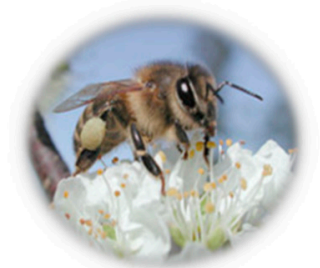

Nectar and pollen availability

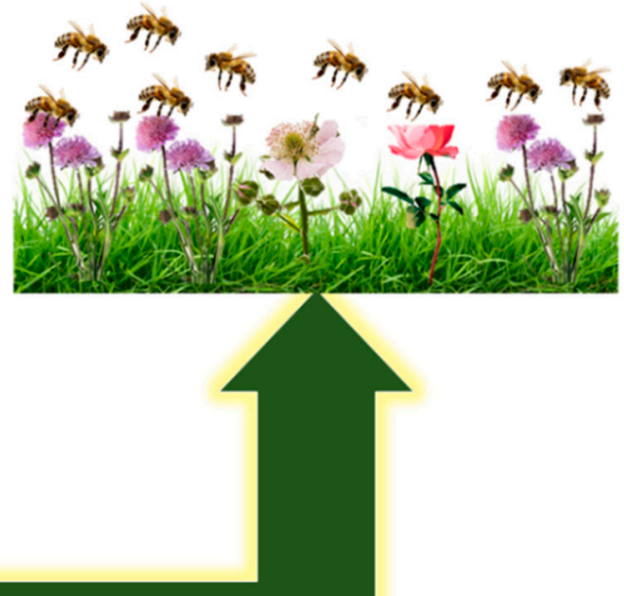

\section{Factors influence on bee visitation to flowers}

Figure 1. Factors that influence bee visitation.

Finally, the quantity and/or quality of pollen and nectar produced may affect the visitation of flowers by bees. Nectar and pollen are sources of energy, protein, and lipids for bees, and other pollinators [144] and bees are drawn to plants to provide food for their young [145]. Solitary bees search for pollen but rarely nectar [132], whereas honey bees search for flowers with larger amounts of nectar [146]. It has previously been shown that the composition of wild bee populations that visit various plants can best be explained by variations in the flowering areas, height of the flowers, and amount of pollen deposited in the flowers [147]. For example, British bumble bees differentiate between Mimulus guttatus plants on the basis of their pollen content and quality, with a significant association between visitation and pollen content [148]. Furthermore, both wild bees and honey bees forage on sunflowers for their nectar sugar, with the number of flower visits increasing significantly with an increasing nectar sugar level and decreasing during the corolla period but seeming to be unaffected by nectar sugar composition. Wild bees make more visits to sunflowers that provide pollen (male-fertile plants) and honey bees favor pollen-free flowers (malesterile plants) [146]. Cover crops, particularly low-diversity mixes that include buckwheat and Phacelia spp., provide a high abundance of flowers throughout the summer, resulting in excessive bee visitation rates, with Phacelia spp. being more appealing to honey bees and bumble bees, while sunflowers and local wildflowers are more appealing to solitary bees [149].

Honey bees visit native and cultivated plants at comparable average rates that are independent of floral abundance, therefore increasing their visitation rates for the highly abundant plants, whereas the visitation rate of wild pollinators is higher for cultivated plants than for native plants. For example, knapweed (Centaurea spp.) is a widespread and often locally important plant for honey bees, as it is favored and regularly visited for its pollen and nectar [150]. In France, the visitation ratio of large solitary bees, wild beetle pollinators, and bumble bees was negatively impacted by the abundance of honey bees colonies [151].

One behavior that some bees have developed during their visitation is buzz pollination, whereby the bees make vibrations to remove and collect the pollen from the fruit set, fruit mass, and flowers during fertilization [152]. About half of bee species can perform buzz behavior, such as large carpenter bees, minute sweat bees and bumble bees, but they differ in their buzz properties $[153,154]$. This vibration is the best means for extracting pollen 
from plant species that have small pores on their anthers [155]. During this behavior, the bee bites the anther of the flower and makes vibrations with its thoracic muscles while in direct contact with the flower, causing the vibrations to be transmitted into the flower [156]. There are several ways of performing this buzzing behavior. For example, the flowers of Pedicularis spp. have long anthers and narrow corolla tubes, so bees make their vibrations on these corolla tubes for rapid pollen extraction $[157,158]$. Therefore, this behavior is related to the functional specificity of flowers, particularly in those flowers in which pollen release requires modification of the stamens. Buzz pollination takes its name from the audible sound made during the vibration and is also often called sonication [157]. It is currently believed that this vibration behavior for pollen collection is not performed by any other animal [70]. However, further research is required to determine whether some flies also use vibration behavior to collect pollen.

Most bees visit flowers during the daylight; only five of nine families of bees search for flowers in dim light [159]. Nocturnal bees have different factors that affects their flower trips, including light intensity and temperature. Temperatures and light levels are lower at night than during the day, and this can affect, in particular, the behavior of nocturnal bees [29].

\section{Challenges Faced in Bee Pollination}

Bees are surrounded by several variables that affect their role as pollinators, such as pathogens, nutritional shortages, climate change, and deforestation (Figure 2) [160-163]. Pathogens such as viruses and bacterial infections have a negative effect on bee health and longevity, threatening pollination services of crops and wild plants [164]. Viral infections affect bee immune systems, causing disease in entire colonies [165]. Colony collapse disorder (CCD) is a phenomenon whereby there are unexplained, rapid losses of adult working bees in managed bee colonies (e.g., honey bee colonies in the USA), resulting in only the queen and a few nursing bees remaining [166]. This problem faces many beekeepers [167]. In the USA, the parasites Nosema ceranae and Nosema apis also have highly pathogenic effects, causing huge honey bee losses [168]. Conroy et al. [169] found that both nutritional limitation and pathogens have a large effect on bumble bees, with a lack of pollen and low nectar sugar levels leading to reduced pollination and, consequently, a decline in production. In addition to the natural factors affecting bee pollination, the use of pesticides, such as acetamiprid and ergosterol-inhibiting fungicides, threaten pollination services [170]. The residues of pesticides and other synthetic products remain in the nectar and pollen collected by bees, leading to neurotoxicity, immune deficiency, behavioral changes, and chronic ailments [171,172]. The application of neonicotinoid insecticides, which are systemic insecticides that are transferred into the pollen and nectar of many pollinated crops, is one of the main co-factors associated with bee losses [173,174]. Spraying agrochemicals such as fungicides, insecticides, and pesticides cause contamination, toxicity, and declines in the quality and quantity of nutrients in the pollen and nectar, leading to poor colony health and hence threatening the survival of bees [175,176].

Recently, the Environmental Protection Agency (EPA) has been investigating the effect of pesticides on the immune system of bees [177], while the European Food Safety Authority assessment provides information on the chronic toxicity of pesticides on bees [178]. The effect of neem-based insecticide (botanical) and pyrethroid insecticides, deltamethrin and the fungicides thiophanate-methyl and chlorothalonil (synthetic) insecticides on the melon (Cucumis melo L.) has been investigated. Both insecticides and pesticides not only reduced the visitation intensity of bees but also lead to lower melon yield [179]. Therefore, good nutrition has a direct effect on the immune function and an indirect effect on energy availability [161]. 


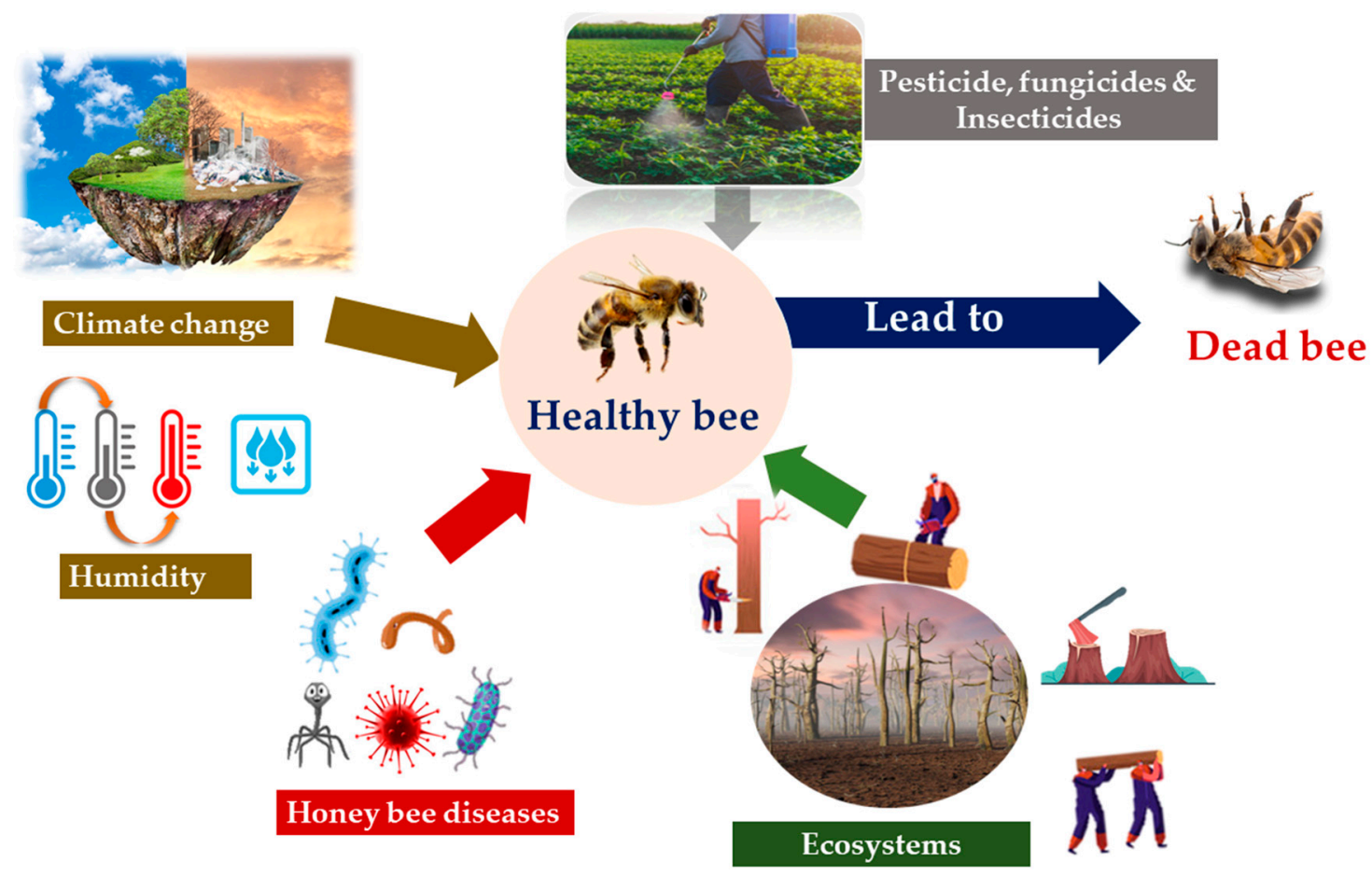

Figure 2. Challenges faced in bee pollination.

Many factors also affect the growth, reproduction, and survival of bees, such as high temperatures, and humidity, reducing not only the biodiversity of bees and other pollinators but also agricultural production [160]. Most bees visit flowers during the daylight, but some bee families search for flowers in dim light [159]. Nocturnal bees settle their flower trips by light intensity and temperature [180].

Deforestation can also affect bee populations (Figure 2) [163]. For example, the abundance of bumble bees in the tropical agricultural highlands of Guatemala increased with the increase in forests and semi-natural vegetation in local areas, but was not influenced by season [181]. Habitat loss and climate change also affect honey bees worldwide, causing pollinator losses [182-184].

\section{Bee Pollination vs. Non-Bee Pollination}

Bees are considered the most effective pollinators; however, the contribution of other insect pollinators cannot be considered negligible, as they serve to increase and stabilize crop pollination and rely on these plants for the supply of pollen and nectar $[17,149,184]$. The main groups of other insect pollinators are butterflies, moths (Lepidoptera), some flies (Diptera), and beetles (Coleoptera) [17,185].

\subsection{Hoverflies vs. Bees}

Hoverflies (Diptera: Syrphidae) are considered the most anthophilous family in the order Diptera [186]. Episyrphus balteatus DeGeer is one of the most common hoverfly species to usually be found in agricultural areas, and several recent studies have confirmed its contribution as a pollinator of many crops around the world [187]. One crop that is pollinated by hoverflies E. balteatus is oilseed rape, which is an important crop in temperate regions. It has been shown that when E. balteatus is involved in the pollination services of this crop, sufficient numbers of seeds per pod are produced, demonstrating the ability of $E$. balteatus as a pollinator of edible crops [188]. The drone fly, Eristalis tenax L., has also been reported as a successful pollinator of numerous managed crops, such as pak choi (Brassica rapa subsp. chinensis) and onion in New Zealand [189], onion, spring turnip rape (Brassica rapa L. subsp. oleifera), and carrot (Daucus carota L. subsp. sativus) in Germany [190], sweet pepper (C. annuum) in Canada [191], and kiwifruit in Italy [192]. Consequently, according 
to Brad and Megan, E. tenax L. is often kept in large numbers in fields during the crop flowering period [189].

A study in Germany looked at the impact of pollination by the solitary mason bee $O$. rufa and two hoverfly species (E. tenax and E. balteatus) on oilseed rape. This study showed that the fruit yield and number of seeds per pod improved with an increase in bee abundance relative to hoverfly abundance, and that five-fold higher density of hoverflies than red mason bees were required to achieve the same fruit sets and yields. Thus, mason bees were more effective pollinators of this crop than hoverflies [122].

\subsection{Butterflies vs. Bees}

Around 180,000 species of butterfly and moth (Lepidoptera) are reported and make up to about $10 \%$ of all recognized insect species. Butterflies represent approximately $10 \%$ of Lepidoptera [193] and tend to visit psychrophilic flowers that offer small to medium volumes of dilute nectar. These flowers are characterized by brightly colored petals with a mild and pleasant aroma and a flat platform that enables the butterflies to land in the inflorescence. Large- to medium-sized butterflies act as pollinators via their wings [194]. Gloriosa minor Rendle (Colchicaceae) is a dry land floral plant in Kenya that depends on butterflies for pollination, and consequently the production of seeds, which are a source of colchicine [195]. Caesalpinia pulcherrima was pollinated mainly via butterflies which carry the pollen on their wings [196].

Angadenia berteroi is an endangered species that has large, showy, yellow, and tubular flowers with no notable fragrance. The tubular shape of these flowers gives them a complex structure, so any pollinators that are attracted to this plant should have body parts that are specifically adapted to this morphology, including mouthparts that are long enough to find the nectar $[197,198]$. Both bees and butterflies visit $A$. berteroi, allowing a comparison of their efficiency. The long-tongued bees' heads are wider than the apical portion of the pollen chamber, forcing them to touch the reproductive parts of the flower, and these bees rarely revisit the same flowers. Long-tongued bees appear to be efficient in gathering nectar and transporting pollen $[117,199]$. By contrast, the two groups of butterflies that visit the flowers [skippers (Hesperiidae and non-skippers) carry very small amounts of pollen on their proboscides, do not deposit this pollen on the stigmas of the flowers, and frequently visit the same flowers, thus appearing to act as nectar thieves. The frequent visitation of the same flower by an insect is known to have negative effects. For instance, flower re-visitation can lead to abortion of the fruit and ovule due to self-pollen deposition on the stigma, explaining why the mouthparts are associated with the efficacy of the pollination process [117].

\subsection{Moths vs. Bees}

Moths can be categorized as having a crepuscular or nocturnal lifestyle and are recognized as one of the main pollinators of a large variety of plant species in different habitats around the world [200]. The information on the role of moth pollination in natural habitats is available where about 227 flowers have been pollinated by moths [193]. Moths are frequent floral visitors, and there are a number of encounters between plant species and moths. Moths pollinate approximately $40 \%$ of plant species in rural landscape environments, such as meadows, pastures, old farms, field edges, and roadsides. Consequently, the role of moths in agricultural environments is often attributed to their pollination of non-crop plants, which contributes to increasing the biodiversity in agro-ecosystems, offering a widely appreciated ecological function [201,202]. Moths may also pollinate some unique plant species, such as some orchids. At present, however, the role of moths in pollination is likely underestimated due to the limited number of studies on this topic [203-205].

An evaluation of insect pollination levels on sunflower crops in the central Darling Downs during the day and night showed that Western honey bees were the most recurrent visitors, with populations averaging 65.3 bees per 100 flower heads across 42 crops through mid-morning [110]. By contrast, Helicoverpa armigera Hübner moths were observed visiting 
the plants during the night, averaging 3.9 individuals per 100 flower heads between 7 and $8 \mathrm{pm}$ and being registered in 33 crops. Thus, moths visited the flowers for less than $2 \mathrm{~h}$ per night whereas bees were active for $9 \mathrm{~h}$. The small population size and low level of activity of moths indicated that bees played a significant role in sunflower pollination in this area [110].

\subsection{Beetles vs. Bees}

Beetles (Coleoptera) belong to one of the most diverse insect orders and their role in pollination systems is increasingly being recognized. Some flowering plants depend on pollination by certain types of beetles. For example, species in the subfamily Cetoniinae (Scarabaeidae) are common pollinators in the tropics [206]. More than 184 species of angiosperms are exclusively pollinated by beetles (e.g., Magnolia in Magnoliaceae) $[207,208]$. Some beetles use flowers as rendezvous sites besides their usage in their food which enhances their role as pollinators. Unlike tropical pollinators, beetles depend on odor to find flowers, while Hopliine beetles exclusively use visual indications and, even without nourishment or smell, are attracted to bright colors [209]. Beetles are always associated with the pollination of open bowl-shaped flowers [207]. Beetles were found to be the second most important insect group contributing to pollination services in both Lambir $(27 \%)$ and Kakachi $(17 \%)$ in Malaysia and India, respectively. Both bees and beetles together represent more than $60 \%$ of the pollination services of tree species in Lambir and $34 \%$ of those in Kakachi [210]. Bees play the main pollinator role in Lambir (32\%) followed by beetle-pollinated species (20\%) [211], but the beetle Hopliini sp. (Scarabaeidae) is one of the most effective pollinators in the southwestern area of Cape Province and Namaqualand $[212,213]$. Therefore, there is a need for further studies to clarify the ecological role of beetles and their effectiveness as pollinators [214].

\subsection{Thrips vs. Bees}

Thrips (Thysanoptera) are pollinators of plant species, however they are still poorly studied [215]. These tiny insects have piercing-sucking mouthparts and are usually noticed on flowers, where they depend on nectar, pollen, or the cell content of plant tissues in their food [216]. Thrips have been noticed in the flowering period of coffee species C. arabica L. and C. canephora L. in the southern state of Chiapas, Mexico in three flowering seasons (2013-2015). Several species of thrips on coffee flower were noticed to be carrying a few pollen grains on their bodies [217]. Bees have increased fruit production of coffee by $50 \%$ more than wind in shaded coffee agro-forests, South India. The role of other insect visitors with bees including Thysanoptera in coffee was insignificant as they did not touch the flower anther or stigma enough times in addition to performing infrequent visitation [115].

\subsection{Wasps vs. Bees}

Social wasps (Hymenoptera) are among the pollinators in the Neotropical region. As predators, they can behave as flower visitors [218,219]. Many factors attract wasps to flowers such as flower color and shape. Wasps are attracted to reddish brown, dirty purple, and dirty brown flowers. Schremmer (1962) has noticed that wasps are attracted to small flowers with bulbous, wide entrances and sucrose-rich nectar $[115,220]$. Floral scent is one of the main factors attracting wasps. For example, social wasps are the main pollinators of Epipactis helleborine L. due to their scent [221,222]. Another study has been done on the coconut flower in the presence of wasps and honey bees. The wasps (Polistes crinita Felt) failed as a pollinator because of their disability in loading adequate amounts of pollen and their behavior in deterring the honey bee. In contrast, honey bees were effective as pollinators to coconut [95].

\section{Conclusions}

Bee pollination provides a wide variety of benefits to humanity, contributing to food processing, raw materials, medicines, fibers, social, cultural values, and the maintenance 
of biodiversity and environmental protections. Bees' pollination has direct effects on the profitability and productivity of a substantial amount of global crop varieties, including most vegetables, seeds, and nuts, and some high-value agricultural products, such as coffee, cocoa, and rapeseed. Currently, $5-8 \%$ of all global crop production would be lost without the pollination services provided by bees, necessitating changes in the human diet and the expansion of agricultural lands to resolve shortfalls in crop production. Bees are faced with many challenges that can distort their lives, including shifts in land use, climate change, pesticides, genetics and cultivation management. Concerns regarding the decline of domestic and wild bees have intensified the need to encourage the usage of the wild pollinators on agricultural lands. As wild bee trips have increased with the development of high-diversity bee habitats in the surrounding landscape, the restoration of high-diversity bee habitats is necessary to increase free pollination levels. A secure atmosphere for bees should be provided to produce healthy crops. The use of insecticides and pesticides is damaging to human health because both crops and bee products become contaminated with agrochemicals that humans must eventually ingest. Although the roles played by non-bee pollinators cannot be ignored, bee pollination remains a precious asset that should be protected. Bee pollination must be enhanced not only to improve environmental balance but also to maintain food security worldwide. The role played by bees is important for worldwide crops and certain medicinal plants, with significant effects on quantity and quality. Researchers should focus their attention on studying the impacts that bees have on crop quality, which should provide more detailed data regarding how bees can alter the chemistry of certain crops.

Author Contributions: Conceptualization, H.R.E.-S.; validation, H.R.E.-S. and S.A.M.K.; writingoriginal draft preparation, E.H.E., A.A.S. and A.A.A.E.-W.; writing-review and editing, S.A.M.K., A.F.A., S.G.M., M.F.A., C.Z., S.H.D.M., M.M.A.-D., M.F.H., G.K., Y.A.N., M.B., M.A.M.D. and H.R.E.S.; supervision, H.R.E.-S.; funding acquisition, H.R.E.-S. All authors have read and agreed to the published version of the manuscript.

Funding: This work was supported by the Swedish Research Council Vetenskapsrådet (VR Grant 2016-05885).

Institutional Review Board Statement: Not applicable.

Informed Consent Statement: Not applicable.

Data Availability Statement: No new data were created or analyzed in this study. Data sharing is not applicable to this article.

Acknowledgments: Authors are very grateful to the Swedish Research links Grant VR 2016-05885 and the Department of Molecular Biosciences, Wenner-Grens Institute, Stockholm University, Sweden, for the financial support.

Conflicts of Interest: The authors declare no conflict of interest.

\section{References}

1. Gill, R.J.; Baldock, K.C.; Brown, M.J.; Cresswell, J.E.; Dicks, L.V.; Fountain, M.T.; Garratt, M.P.; Gough, L.A.; Heard, M.S.; Holland, J.M.O.J. Protecting an ecosystem service: Approaches to understanding and mitigating threats to wild insect pollinators. Adv. Ecol. Res. 2016, 54, 135-206. [CrossRef]

2. Breeze, T.D.; Bailey, A.P.; Balcombe, K.G.; Potts, S.G. Pollination services in the UK: How important are honeybees? Agric. Ecosyst. Environ. 2011, 142, 137-143. [CrossRef]

3. Hristov, P.; Neov, B.; Shumkova, R.; Palova, N. Significance of apoidea as main pollinators. Ecological and economic impact and implications for human nutrition. Diversity 2020, 12, 280. [CrossRef]

4. Sukumaran, A.; Khanduri, V.P.; Sharma, C.M. Pollinator-mediated self-pollination and reproductive assurance in an isolated tree of Magnolia grandiflora L. Ecol. Process. 2020, 9, 45-53. [CrossRef]

5. García-Breijo, F.; Armiñana, J.R.; Garmendia, A.; Cebrián, N.; Beltrán, R.; Merle, H. In vivo pollen tube growth and evidence of self-pollination and prefloral anthesis in cv. Macabeo (Vitis vinifera L.). Agriculture 2020, 10, 647. [CrossRef]

6. MacInnis, G.; Forrest, J.R.K. Field design can affect cross-pollination and crop yield in strawberry (Fragaria $x$ ananassa D.). Agric. Ecosyst. Environ. 2020, 289, 106738-106745. [CrossRef] 
7. Lobo, J.A.; Quesada, M.; Stoner, K.E. Effects of pollination by bats on the mating system of Ceiba pentandra (Bombacaceae) populations in two tropical life zones in Costa Rica. Am. J. Bot. 2005, 92, 370-376. [CrossRef]

8. Zeng, X.; Fischer, G.A. Wind pollination over 70 years reduces the negative genetic effects of severe forest fragmentation in the tropical oak Quercus bambusifolia. Heredity (Edinb). 2020, 124, 156-169. [CrossRef]

9. Van der Kooi, C.J.; Ollerton, J. The origins of flowering plants and pollinators. Science (80-.) 2020, 368, 1306-1308. [CrossRef]

10. Gallai, N.; Salles, J.M.; Settele, J.; Vaissière, B.E. Economic valuation of the vulnerability of world agriculture confronted with pollinator decline. Ecol. Econ. 2009, 68, 810-821. [CrossRef]

11. Meena, N.K.; Lal, G.; Meena, R.S.; Meena, B.M.; Meena, R.D. Pollinator's diversity and abundance on cumin (Cuminum cyminum L.) and their impact on yield enhancement at semi-arid regions. J. Entomol. Zool. Stud. 2018, 6, 1017-1021.

12. Abd El-Wahab, T.E.; Ebadah, I.M.A.; Mahmoud, Y.A. Insect pollinators of anise plants (Pimpinella anisum L.) and the important role of honey bees (Apis mellifera L.) on their yield productivity. Arch. Phytopathol. Plant Prot. 2012, 45, 677-685. [CrossRef]

13. Chambó, E.D.; Garcia, R.C.; de Oliveira, N.T.E.; Duarte-Júnior, J.B. Honey bee visitation to sunflower: Effects on pollination and plant genotype. Sci. Agric. 2011, 68, 647-651. [CrossRef]

14. Patil, P.N.; Pastagia, J.J. Effect of bee pollination on yield of coriander. Coriandrum sativum Linnaeus. Int. J. Plant Prot. 2016, 9 , 79-83.

15. Klein, A.M.; Vaissière, B.E.; Cane, J.H.; Steffan-Dewenter, I.; Cunningham, S.A.; Kremen, C.; Tscharntke, T. Importance of pollinators in changing landscapes for world crops. Proc. R. Soc. B Biol. Sci. 2007, 274, 303-313. [CrossRef] [PubMed]

16. Calderone, N.W. Insect pollinated crops, insect pollinators and US agriculture: Trend analysis of aggregate data for the period 1992-2009. PLoS ONE 2012, 7, e37235. [CrossRef]

17. Rader, R.; Bartomeus, I.; Garibaldi, L.A.; Garratt, M.P.D.; Howlett, B.G.; Winfree, R.; Cunningham, S.A.; Mayfield, M.M.; Arthur, A.D.; Andersson, G.K.S.; et al. Non-bee insects are important contributors to global crop pollination. Proc. Natl. Acad. Sci. USA 2016, 113, 146-151. [CrossRef]

18. Stanley, D.A.; Msweli, S.M.; Johnson, S.D. Native honeybees as flower visitors and pollinators in wild plant communities in a biodiversity hotspot. Ecosphere 2020, 11, e02957. [CrossRef]

19. Rao, S.; Stephen, W.P. Bumble bee pollinators in red clover seed production. Crop Sci. 2009, 49, 2207-2214. [CrossRef]

20. Bänsch, S.; Tscharntke, T.; Gabriel, D.; Westphal, C. Crop pollination services: Complementary resource use by social vs solitary bees facing crops with contrasting flower supply. J. Appl. Ecol. 2021, 58, 476-485. [CrossRef]

21. Greenleaf, S.S.; Kremen, C. Wild bees enhance honey bees' pollination of hybrid sunflower. Proc. Natl. Acad. Sci. USA 2006, 103, 13890-13895. [CrossRef] [PubMed]

22. Giannini, T.C.; Cordeiro, G.D.; Freitas, B.M.; Saraiva, A.M.; Imperatriz-Fonseca, V.L. The dependence of crops for pollinators and the economic value of pollination in Brazil. J. Econ. Entomol. 2015, 108, 849-857. [CrossRef] [PubMed]

23. Potts, S.G.; Imperatriz-Fonseca, V.; Ngo, H.T.; Aizen, M.A.; Biesmeijer, J.C.; Breeze, T.D.; Dicks, L.V.; Garibaldi, L.A.; Hill, R.; Settele, J.; et al. Safeguarding pollinators and their values to human well-being. Nature 2016, 540, 220-229. [CrossRef] [PubMed]

24. Lautenbach, S.; Seppelt, R.; Liebscher, J.; Dormann, C.F. Spatial and temporal trends of global pollination benefit. PLoS One 2012, 7, e35954. [CrossRef]

25. Aizen, M.A.; Garibaldi, L.A.; Cunningham, S.A.; Klein, A.M. How much does agriculture depend on pollinators? Lessons from long-term trends in crop production. Ann. Bot. 2009, 103, 1579-1588. [CrossRef]

26. Montoya, D.; Gaba, S.; de Mazancourt, C.; Bretagnolle, V.; Loreau, M. Reconciling biodiversity conservation, food production and farmers' demand in agricultural landscapes. Ecol. Modell. 2020, 416, 108889-108909. [CrossRef]

27. Geeraert, L.; Aerts, R.; Berecha, G.; Daba, G.; De Fruyt, N.; D’hollander, J.; Helsen, K.; Stynen, H.; Honnay, O. Effects of landscape composition on bee communities and coffee pollination in Coffea arabica production forests in southwestern Ethiopia. Agric. Ecosyst. Environ. 2020, 288, 106706-106717. [CrossRef]

28. Luo, D.; Silva, D.P.; De Marco Júnior, P.; Pimenta, M.; Caldas, M.M. Model approaches to estimate spatial distribution of bee species richness and soybean production in the Brazilian Cerrado during 2000 to 2015. Sci. Total Environ. 2020, 737, 139674. [CrossRef]

29. Sáez, A.; Aizen, M.A.; Medici, S.; Viel, M.; Villalobos, E.; Negri, P. Bees increase crop yield in an alleged pollinator-independent almond variety. Sci. Rep. 2020, 10, 3177-3183. [CrossRef]

30. Losey, J.E.; Vaughan, M. The economic value of ecological services provided by insects. Bioscience 2006, 56, 311-323. [CrossRef]

31. Esquivel, I.L.; Coulson, R.N.; Brewer, M.J. A native bee, melissodes tepaneca (Hymenoptera: Apidae), benefits cotton production. Insects 2020, 11, 487. [CrossRef]

32. Stein, K.; Coulibaly, D.; Stenchly, K.; Goetze, D.; Porembski, S.; Lindner, A.; Konaté, S.; Linsenmair, E.K. Bee pollination increases yield quantity and quality of cash crops in Burkina Faso, West Africa. Sci. Rep. 2017, 7, 17691-17700. [CrossRef] [PubMed]

33. Kasina, J.M.; Mburu, J.; Kraemer, M.; Holm-Mueller, K. Economic benefit of crop pollination by bees: A case of kakamega small-holder farming in Western Kenya. J. Econ. Entomol. 2009, 102, 467-473. [CrossRef] [PubMed]

34. Hipólito, J.; Sousa, B.d.S.B.; Borges, R.C.; de Brito, R.M.; Jaffé, R.; Dias, S.; Imperatriz Fonseca, V.L.; Giannini, T.C. Valuing nature's contribution to people: The pollination services provided by two protected areas in Brazil. Glob. Ecol. Conserv. 2019, 20 , e00782. [CrossRef]

35. Orges, R.C.B.; Rito, R.M.B.; Onseca, V.L.I.M.; Iannini, T.C.G. The value of crop production and pollination services in the Eastern Amazon. Neotrop. Entomol. 2020, 49, 545-556. [CrossRef] 
36. Reilly, J.R.; Artz, D.R.; Biddinger, D.; Bobiwash, K.; Boyle, N.K.; Brittain, C.; Brokaw, J.; Campbell, J.W.; Daniels, J.; Elle, E.; et al. Crop production in the USA is frequently limited by a lack of pollinators. Proc. R. Soc. B Biol. Sci. 2020, 287, 20200922-20200930. [CrossRef] [PubMed]

37. Hall, M.A.; Jones, J.; Rocchetti, M.; Wright, D.; Rader, R. Bee visitation and fruit quality in berries under protected cropping vary along the length of polytunnels. J. Econ. Entomol. 2020, 113, 1337-1346. [CrossRef]

38. Valido, A.; Rodríguez-Rodríguez, M.C.; Jordano, P. Honeybees disrupt the structure and functionality of plant-pollinator networks. Sci. Rep. 2019, 9, 4711-4721. [CrossRef]

39. Garantonakis, N.; Varikou, K.; Birouraki, A.; Edwards, M.; Kalliakaki, V.; Andrinopoulos, F. Comparing the pollination services of honey bees and wild bees in a watermelon field. Sci. Hortic. (Amsterdam) 2016, 204, 138-144. [CrossRef]

40. Hung, K.-L.J.; Kingston, J.M.; Albrecht, M.; Holway, D.A.; Kohn, J.R. The worldwide importance of honey bees as pollinators in natural habitats. Proc. R. Soc. B Biol. Sci. 2018, 285, 20172140-20172147. [CrossRef]

41. Streinzer, M.; Brockmann, A.; Nagaraja, N.; Spaethe, J. Sex and caste-specific variation in compound eye norphology of five honeybee species. PLoS ONE 2013, 8, e57702. [CrossRef] [PubMed]

42. Shin, D.; Choi, W.T.; Lin, H.; Qu, Z.; Breedveld, V.; Meredith, J.C. Humidity-tolerant rate-dependent capillary viscous adhesion of bee-collected pollen fluids. Nat. Commun. 2019, 10, 1-9. [CrossRef] [PubMed]

43. Ghosh, S.; Jeon, H.; Jung, C. Foraging behaviour and preference of pollen sources by honey bee (Apis mellifera) relative to protein contents. J. Ecol. Environ. 2020, 44, 4-10. [CrossRef]

44. Seo, H.J.; Song, J.; Yoon, H.J.; Lee, K.Y. Effects of nectar contents on the foraging activity of honeybee (Apis mellifera) on Asian pear (Pyrus pyrifolia Nakai). Sci. Hortic. (Amsterdam) 2019, 245, 185-192. [CrossRef]

45. Morse, R.A. and Calderone, N.W. The value of honey bees as pollinators of U.S. crops in 2000. Bee Cult. 2000, 128, 1-15. [CrossRef]

46. Naumann, K.; Winston, M.L.; Slessor, K.N.; Smirle, M.J. Synthetic honey bee (Hymenoptera: Apidae) queen mandibular gland pheromone applications affect pear and sweet cherry pollination. J. Econ. Entomol. 1994, 87, 1595-1599. [CrossRef]

47. Rajagopal, D.; Eswarappa, G.; Raju, A.J.S. Pollination Potentiality of Honeybees in Increasing Productivity of Guava in Karnataka. In Changing Trends in Pollen Spore Research; Today and Tomorrow's Printers \& Publishers: New Delhi, India, 2005; pp. 131-141. ISBN 8173715173.

48. Meléndez-Ramírez, V.; Parra-Tabla, V.; Kevan, P.G.; Ramírez-Morillo, I.; Harries, H.; Fernández-Barrera, M.; Zizumbo-Villareal, D. Mixed mating strategies and pollination by insects and wind in coconut palm (Cocos nucifera L. (Arecaceae)): Importance in production and selection. Agric. For. Entomol. 2004, 6, 155-163. [CrossRef]

49. Ewies, M.A.; EL-Sahhar, K.F. Observations on the behaviour of honeybees on onion and their effects on seed yield. J. Apic. Res. 1977, 16, 194-196. [CrossRef]

50. Bartomeus, I.; Potts, S.G.; Steffan-Dewenter, I.; Vaissière, B.E.; Woyciechowski, M.; Krewenka, K.M.; Tscheulin, T.; Roberts, S.P.M.; Szentgyörgyi, H.; Westphal, C.; et al. Contribution of insect pollinators to crop yield and quality varies with agricultural intensification. PeerJ 2014, 2014, e328-e347. [CrossRef]

51. Abd El-Wahab, T.E.; Ebadah, I.M.A. Impact of honeybee and other insect pollinators on the seed setting and yield production of black cumin Nigella sativa L. J. Basic. Appl. Sci. Res 2011, 1, 622-626.

52. Saboor, N.; Muhammad, A.; Muhammad, A.R.; Younisand, A. Role of pollinators in recommended and densely grown black cumin (Nigella sativa L.) yield at Dera Ismail Khan. J. Entomol. Zool. Stud. 2018, 6, 983-986.

53. Bendifallah, L.; Louadi, K.; Doumandji, S. Bee fauna potential visitors of coriander flowers Coriandrum sativum L. (Apiaceae) in the Mitidja area (Algeria). J. Apic. Sci. 2013, 57, 59-70. [CrossRef]

54. Geslin, B.; Aizen, M.A.; Garcia, N.; Pereira, A.; Vaissière, B.E. The impact of honey bee colony quality on crop yield and farmers' profit in apples and pears. Agric. Ecosyst. Environ. 2017, 248, 153-161. [CrossRef]

55. Chautá-mellizo, A.; Campbell, S.A.; Argenis, M.; Thaler, J.S.; Poveda, K. Effects of natural and artificial pollination on fruit and offspring quality. Basic Appl. Ecol. 2012, 13, 524-532. [CrossRef]

56. Isaacs, R.; Kirk, A.K. Pollination services provided to small and large highbush blueberry fields by wild and managed bees. $J$. Appl. Ecol. 2010, 47, 841-849. [CrossRef]

57. Crowther, L.P.; Wright, D.J.; Richardson, D.S.; Carvell, C.; Bourke, A.F.G. Spatial ecology of a range-expanding bumble bee pollinator. Ecol. Evol. 2019, 9, 986-997. [CrossRef]

58. Velthuis, H.H.W.; Van Doorn, A. A century of advances in bumblebee domestication and the economic and environmental aspects of its commercialization for pollination. Apidologie 2006, 37, 421-451. [CrossRef]

59. Peat, J.; Darvill, B.; Ellis, J.; Goulson, D. Effects of climate on intra- and interspecific size variation in bumble-bees. Funct. Ecol. 2005, 19, 145-151. [CrossRef]

60. Fijen, T.P.M.; Scheper, J.A.; Boom, T.M.; Janssen, N.; Raemakers, I.; Kleijn, D. Insect pollination is at least as important for marketable crop yield as plant quality in a seed crop. Ecol. Lett. 2018, 21, 1704-1713. [CrossRef]

61. Nayak, R.K.; Rana, K.; Sharma, H.K.; Rana, V.S.; Thakur, M. Influence of bumble bee pollination on quantitative and qualitative parameters of kiwifruit. Indian J. Hortic. 2019, 76, 294-299. [CrossRef]

62. Shipp, J.L.; Whitfield, G.H.; Papadopoulos, A.P. Effectiveness of the bumble bee, Bombus impatiens Cr.(Hymenoptera: Apidae), as a pollinator of greenhouse sweet pepper. Sci. Hortic. (Amsterdam) 1994, 57, 29-39. [CrossRef]

63. Roldán Serrano, A.; Guerra-Sanz, J.M. Quality fruit improvement in sweet pepper culture by bumblebee pollination. Sci. Hortic. (Amsterdam) 2006, 110, 160-166. [CrossRef] 
64. Desjardins, È.C.; De Oliveira, D. Commercial bumble bee Bombus impatiens (Hymenoptera: Apidae) as a pollinator in lowbush blueberry (Ericale: Ericaceae) fields. J. Econ. Entomol. 2006, 99, 443-449. [CrossRef]

65. Yankit, P.; Rana, K.; Kumar Sharma, H.; Thakur, M.; Thakur, R.K. Effect of bumble bee pollination on quality and yield of Tomato (Solanum lycopersicum Mill.) grown under protected conditions. Int. J. Curr. Microbiol. Appl. Sci. 2018, 7, 257-263. [CrossRef]

66. Normandeau Bonneau, M.; Samson-Robert, O.; Fournier, V.; Chouinard, G. Commercial bumble bee (Bombus impatiens) hives under exclusion netting systems for apple pollination in orchards. Renew. Agric. Food Syst. 2020, 36, 234-244. [CrossRef]

67. Quezada-Euán, J.J.G. Stingless Bees of Mexico. In Stingless Bees of Mexico: The Biology, Management and Conservation of an Ancient Heritage; Springer: New York, NY, USA, 2018; pp. 1-37. ISBN 9783319777849.

68. Ramírez, V.M.; Ayala, R.; González, H.D. Crop pollination by stingless bees. In Pot-Pollen in Stingless Bee Melittology; Springer: Cham, Switzerland, 2018; pp. 139-153.

69. Eickwort, G.C.; Ginsberg, H.S. Foraging and mating behavior in Apoidea. Annu. Rev. Entomol. 1980, 25, 421-446. [CrossRef]

70. De Luca, P.A.; Vallejo-Marín, M. What's the "buzz" about? The ecology and evolutionary significance of buzz-pollination. Curr. Opin. Plant Biol. 2013, 16, 429-435. [CrossRef]

71. Del Sarto, M.C.L.; Peruquetti, R.C.; Campos, L.A.O. Evaluation of the neotropical stingless bee Melipona quadrifasciata (Hymenoptera: Apidae) as pollinator of greenhouse tomatoes. J. Econ. Entomol. 2005, 98, 260-266. [CrossRef]

72. Solange, A.B.S.; Ana, C.R.; Luci, R.B. Pollination of Cucumber Cucumis sativus L. (Cucurbitales: Cucurbitaceae), by the stingless bees Scaptotrigona aff. depili Moure and Nannotrigona testaceicornis Lepeletier (Hymenoptera: Meliponini) in greenhouses. Neotrop. Entomol. 2008, 37, 506-512.

73. Azmi, W.A.; Ghazi, R.; Sultan, U.; Abidin, Z.; Chuah, T.; Mara, U.T. Effects of stingless bee (Heterotrigona itama) pollination on greenhouse cucumber (Cucumis sativus). Malaysian Appl. Biol. 2017, 46, 51-55.

74. Azmi, W.A.; Sembok, W.Z.W.; Yusuf, N.; Hatta, M.F.M.; Salleh, A.F.; Hamzah, M.A.H.; Ramli, S.N. Effects of pollination by the indo-Malaya stingless bee (Hymenoptera: Apidae) on the quality of greenhouse- produced rockmelon. J. Econ. Entomol. 2019, 112, 20-24. [CrossRef]

75. Roselino, A.C.; Santos, S.B.; Hrncir, M.; Bego, L.R. Differences between the quality of strawberries (Fragaria $x$ ananassa) pollinated by the stingless bees Scaptotrigona aff. depilis and Nannotrigona testaceicornis. Genet. Mol. Res. 2009, 8, 539-545. [CrossRef]

76. Ilva, P.N.U.; Rncir, M.H.; Inês, C.; Ilva, S. Stingless bees, Melipona fasciculata, as efficient pollinators of eggplant (Solanum melongena) in greenhouses. Apidology 2013, 44, 537-546. [CrossRef]

77. Leys, R.; Cooper, S.J.B.; Schwarz, M.P. Molecular phylogeny of the large carpenter bees, genus Xylocopa (Hymenoptera: Apidae), based on mitochondrial DNA sequences. Mol. Phylogenet. Evol. 2000, 17, 407-418. [CrossRef]

78. Somanathan, H.; Saryan, P.; Balamurali, G.S. Foraging strategies and physiological adaptations in large carpenter bees. J. Comp . Physiol. A Neuroethol. Sensory, Neural, Behav. Physiol. 2019, 205, 387-398. [CrossRef] [PubMed]

79. Keasar, T. Large carpenter bees as agricultural pollinators. Psyche A J. Entomol. 2010, 2010, 1-7. [CrossRef]

80. Richards, M.H. Built environments influence carpenter bee sociality and vice versa. Insectes Soc. 2020, 67, 201-202. [CrossRef]

81. Raju, A.J.S.; Rao, S.P. Nesting habits, floral resources and foraging ecology of large carpenter bees (Xylocopa latipes and Xylocopa pubescens) in India. Curr. Sci. 2006, 1210-1217.

82. Halder, S.; Ghosh, S.; Khan, R.; Khan, A.A.; Perween, T.; Hasan, M.A. Role of pollination in fruit crops: A review. Pharma Innov. J. 2019, 8, 695-705.

83. Barrera, W.B., Jr.; Trinidad, K.A.D.; Presas, J.A. Hand pollination and natural pollination by carpenter bees (Xylocopa spp.) in Passiflora edulis Sims. f. flavicarpa Deg. (yellow passion fruit). J. Apic. Res. 2020. [CrossRef]

84. Silveira, M.V.; Abot, A.R.; Nascimento, J.N.; Rodrigues, E.T. Is manual pollination of yellow passion fruit completely dispensable? Sci. Hortic. (Amsterdam) 2012, 146, 99-103. [CrossRef]

85. Hogendoorn, K.; Steen, Z.; Schwarz, M.P. Native Australian carpenter bees as a potential alternative to introducing bumble bees for tomato pollination in greenhouses. J. Apic. Res. 2000, 39, 67-74. [CrossRef]

86. Adi, S.; Avi, S.; Tamar, K. The carpenter bee Xylocopa pubescens as an agricultural pollinator in greenhouses. Apidologie 2007, 38, 508-517.

87. Batra, S.W. Solitary bees. Sci. Am. 1984, 250, 120-127. [CrossRef]

88. Biesmeijer, J.C.; Roberts, S.P.M.; Reemer, M.; Ohlemüller, R.; Edwards, M.; Peeters, T.; Schaffers, A.P.; Potts, S.G.; Kleukers, R.; Thomas, C.D. Parallel declines in pollinators and insect-pollinated plants in Britain and the Netherlands. Science 2006, 313, 351-354. [CrossRef]

89. Kleijn, D.; Winfree, R.; Bartomeus, I.; Carvalheiro, L.G.; Henry, M.; Isaacs, R.; Klein, A.M.; Kremen, C.; M'Gonigle, L.K.; Rader, R.; et al. Delivery of crop pollination services is an insufficient argument for wild pollinator conservation. Nat. Commun. 2015, 6, 1-9. [CrossRef]

90. Garratt, M.P.D.; Breeze, T.D.; Boreux, V.; Fountain, M.T.; McKerchar, M.; Webber, S.M.; Coston, D.J.; Jenner, N.; Dean, R.; Westbury, D.B.; et al. Apple pollination: Demand depends on variety and supply depends on pollinator identity. PLoS ONE 2016, 11, e0153889. [CrossRef]

91. Khan, M.R.; Khan, M.R. The role of honey bees Apis mellifera L. (Hymenoptera: Apidae) in pollination of apple. Pakistan J. Biol. Sci. 2004, 7, 359-362. 
92. Wu, P.; Tscharntke, T.; Westphal, C.; Wang, M.; Olhnuud, A.; Xu, H.; Yu, Z.; van der Werf, W.; Liu, Y. Bee abundance and soil nitrogen availability interactively modulate apple quality and quantity in intensive agricultural landscapes of China. Agric. Ecosyst. Environ. 2021, 305, 107168-107176. [CrossRef]

93. Viana, B.F.; da Encarnacao Coutinho, J.G.; Garibaldi, L.A.; Braganca Castagnino, G.L.; Gramacho, K.P.; Oliveira Silva, F. Stingless bees further improve apple pollination and production. J. Pollinat. Ecol. 2014, 14, 261-269. [CrossRef]

94. Mallinger, R.E.; Gratton, C. Species richness of wild bees, but not the use of managed honeybees, increases fruit set of a pollinator-dependent crop. J. Appl. Ecol. 2015, 52, 323-330. [CrossRef]

95. Free, J.B.; Raw, A.; Williams, I.H. Pollination of coconut (Cocos nucifera L.) in Jamaica by honeybees and wasps. Appl. Anim. Ethol. 1975, 1, 213-223. [CrossRef]

96. Walters, S.A. Honey bee pollination requirements for triploid watermelon. HortScience 2005, 40, 1268-1270. [CrossRef]

97. Boyle, N.K.; Pitts-Singer, T.L. Assessing blue orchard bee (Osmia lignaria) propagation and pollination services in the presence of honey bees (Apis mellifera) in Utah tart cherries. PeerJ 2019, 7, e7639. [CrossRef] [PubMed]

98. Holzschuh, A.; Dudenhöffer, J.H.; Tscharntke, T. Landscapes with wild bee habitats enhance pollination, fruit set and yield of sweet cherry. Biol. Conserv. 2012, 153, 101-107. [CrossRef]

99. Bosch, J.; Osorio-Canadas, S.; Sgolastra, F.; Vicens, N. Use of a managed solitary bee to pollinate almonds: Population sustainability and increased fruit set. Insects 2021, 12,56. [CrossRef]

100. Peña, J.F.; Carabalí, A. Effect of honey bee (Apis mellifera L.) density on pollination and fruit set of avocado (Persea Americana Mill.) cv. Hass. J. Apic. Sci. 2018, 62, 5-14. [CrossRef]

101. Popak, A.E.; Markwith, S.H.; Strange, J. Economic valuation of bee pollination services for passion fruit (Malpighiales: Passifloraceae) cultivation on smallholding Farms in São Paulo, Brazil, using the avoided cost method. J. Econ. Entomol. 2019, 112, 2049-2054. [CrossRef]

102. Malerbo-Souza, D.T.; Nogueira-Couto, R.H.; Couto, L.A. Honey bee attractants and pollination in sweet orange, Citrus sinensis (L.) Osbeck, var. Pera-Rio. J. Venom. Anim. Toxins Incl. Trop. Dis. 2004, 10, 144-153. [CrossRef]

103. Deuri, A.; Rahman, A.; Gogoi, J.; Borah, P.; Bathari, M. Pollinator diversity and effect of Apis cerana F. pollination on yield of mango (Mangifera indica L.). J. Entomol. Zool. Stud. 2018, 6, 957-961.

104. Klatt, B.K.; Holzschuh, A.; Westphal, C.; Clough, Y.; Smit, I.; Pawelzik, E.; Tscharntke, T. Bee pollination improves crop quality, shelf life and commercial value. Proc. Biol. Sci. 2014, 281, 20132440-20132447. [CrossRef]

105. Herrmann, J.D.; Beye, H.; de la Broise, C.; Hartlep, H.; Diekötter, T. Positive effects of the pollinators Osmia cornuta (Megachilidae) and Lucilia sericata (Calliphoridae) on strawberry quality. Arthropod. Plant. Interact. 2019, 13, 71-77. [CrossRef]

106. Howpage, D.; Spooner-Hart, R.N.; Vithanage, V. Influence of honey bee (Apis mellifera) on kiwifruit pollination and fruit quality under Australian conditions. New Zeal. J. Crop Hortic. Sci. 2001, 29, 51-59. [CrossRef]

107. Greenleaf, S.S.; Kremen, C. Wild bee species increase tomato production and respond differently to surrounding land use in Northern California. Biol. Conserv. 2006, 133, 81-87. [CrossRef]

108. Neto, S.; Lima, F.G.; Gonçalves, B.B.; Lima Bergamini, L.; Araújo, B.; Bergamini, R.; Antônio, M.; Elias, S.; Franceschinelli, E.V. Native bees pollinate tomato flowers and increase fruit production. J. Pollinat. Ecol. 2013, 11, 41-45.

109. Munawar, M.S.; Sarwar, G.; Raja, S.; Waghchoure, E.S.; Iftikhar, F.; Mahmood, R. Pollination by honeybee (Apis mellifera) increases seed setting and yield in black seed (Nigella sativa). Int. J. Agric. Biol. 2009, 11, 611-615.

110. Radford, B.J.; Nielsen, R.G.H.; Rhodes, J.W. Agents of pollination in sunflower crops on the central darling downs, queensland. Aust. J. Exp. Agric. 1979, 19, 565-569. [CrossRef]

111. Pires, V.C.; Silveira, F.A.; Sujii, E.R.; Torezani, K.R.S.; Rodrigues, W.A.; Albuquerque, F.A.; Rodrigues, S.M.M.; Salomao, A.N.; Soares Pires, C.S. Importance of bee pollination for cotton production in conventional and organic farms in Brazil. J. Pollinat. Ecol. 2014, 13, 151-160. [CrossRef]

112. Nicodemo, D.; Couto, R.H.N.; Malheiros, E.B.; de Jong, D. Honey bee as an effective pollinating agent of pumpkin. Sci. Agric. 2009, 66, 476-480. [CrossRef]

113. Blettler, D.C.; Fagúndez, G.A.; Caviglia, O.P. Contribution of honeybees to soybean yield. Apidologie 2018, 49, 101-111. [CrossRef]

114. De Milfont, M.O.; Rocha, E.E.M.; Lima, A.O.N.; Freitas, B.M. Higher soybean production using honeybee and wild pollinators, a sustainable alternative to pesticides and autopollination. Environ. Chem. Lett. 2013, 11, 335-341. [CrossRef]

115. Krishnan, S.; Kushalappa, C.G.; Shaanker, R.U.; Ghazoul, J. Status of pollinators and their efficiency in coffee fruit set in a fragmented landscape mosaic in South India. Basic Appl. Ecol. 2012, 13, 277-285. [CrossRef]

116. Asiwe, J.A.N. Insect mediated outcrossing and geneflow in cowpea (Vigna unguiculata (L.) Walp): Implication for seed production and provision of containment structures for genetically transformed cowpea. African J. Biotechnol. 2009, 8, 226-230. [CrossRef]

117. Barrios, B.; Pena, S.R.; Salas, A.; Koptur, S. Butterflies visit more frequently, but bees are better pollinators: The importance of mouthpart dimensions in effective pollen removal and deposition. AoB Plants 2016, 8. [CrossRef]

118. Mandal, E.; Amin, M.R.; Rahman, H.; Akanda, A.M. Abundance and foraging behavior of native insect pollinators and their effect on mustard (Brassica juncea L.). Bangladesh J. Zool 2018, 46, 117-123. [CrossRef]

119. Stanley, J.; Sah, K.; Subbanna, A.R.N.S. How efficient is the Asian honey bee, Apis cerana in pollinating mustard, Brassica campestris var. toria? Pollination behavior, pollinator efficiency, pollinator requirements and impact of pollination. J. Apic. Res. 2017, 56, 439-451. [CrossRef] 
120. Klein, A.M.; Steffan-Dewenter, I.; Tscharntke, T. Fruit set of highland coffee increases with the diversity of pollinating bees. Proc. R. Soc. B Biol. Sci. 2003, 270, 955-961. [CrossRef]

121. Muto, N.A.; Leite, R.O. de S.; Pereira, D.S.; Rogez, H.L.G.; Venturieri, G.C. Impact of the introduction of stingless bee colonies (Scaptotrigona aff. postica) on the productivity of acai (Euterpe oleracea). Rev. Verde Agroecol. Desenvolv. Sustentável 2020, 15, 265-273. [CrossRef]

122. Jauker, F.; Bondarenko, B.; Becker, H.C.; Steffan-Dewenter, I. Pollination efficiency of wild bees and hoverflies provided to oilseed rape. Agric. For. Entomol. 2012, 14, 81-87. [CrossRef]

123. Perrot, T.; Gaba, S.; Roncoroni, M.; Gautier, J.L.; Bretagnolle, V. Bees increase oilseed rape yield under real field conditions. Agric. Ecosyst. Environ. 2018, 266, 39-48. [CrossRef]

124. Bloch, D.; Werdenberg, N.; Erhardt, A. Pollination crisis in the butterfly-pollinated wild carnation Dianthus carthusianorum? New Phytol. 2006, 169, 699-706. [CrossRef]

125. Pashte, V.V.; Kulkarni, S.R. Role of pollinators in qualitative fruit crop production: A review. Trends Biosci. $2015,8,3743-3749$.

126. Papiorek, S.; Junker, R.R.; Alves-dos-Santos, I.; Melo, G.A.R.; Amaral-Neto, L.P.; Sazima, M.; Wolowski, M.; Freitas, L.; Lunau, K. Bees, birds and yellow flowers: Pollinator-dependent convergent evolution of UV patterns. Plant Biol. 2016, 18, 46-55. [CrossRef] [PubMed]

127. Bauer, A.A.; Clayton, M.K.; Brunet, J. Floral traits influencing plant attractiveness to three bee species: Consequences for plant reproductive success. Am. J. Bot. 2017, 104, 772-781. [CrossRef] [PubMed]

128. Hennessy, G.; Harris, C.; Eaton, C.; Wright, P.; Jackson, E.; Goulson, D.; Ratnieks, F.F.L.W. Gone with the wind: Effects of wind on honey bee visit rate and foraging behaviour. Anim. Behav. 2020, 161, 23-31. [CrossRef]

129. Whitney, H.M.; Chittka, L.; Bruce, T.J.A.; Glover, B.J. Conical epidermal cells allow bees to grip flowers and increase foraging efficiency. Curr. Biol. 2009, 19, 948-953. [CrossRef] [PubMed]

130. Rachersberger, M.; Cordeiro, G.D.; Schäffler, I.; Dötterl, S. Honeybee pollinators use visual and floral scent cues to find apple (Malus domestica) flowers. J. Agric. Food Chem. 2019, 67, 13221-13227. [CrossRef] [PubMed]

131. Varassin, I.G.; Trigo, J.R.; Sazima, M. The role of nectar production, flower pigments and odour in the pollination of four species of Passiflora (Passifloraceae) in south-eastern Brazil. Bot. J. Linn. Soc. 2001, 136, 139-152. [CrossRef]

132. Gresty, C.E.A.; Clare, E.; Devey, D.S.; Cowan, R.S.; Csiba, L.; Malakasi, P.; Lewis, O.T.; Willis, K.J. Flower preferences and pollen transport networks for cavity-nesting solitary bees: Implications for the design of agri-environment schemes. Ecol. Evol. 2018, 8, 7574-7587. [CrossRef]

133. Prado, S.G.; Collazo, J.A.; Marand, M.H.; Irwin, R.E. The influence of floral resources and microclimate on pollinator visitation in an agro-ecosystem. Agric. Ecosyst. Environ. 2021, 307, 107196-107204. [CrossRef]

134. Bradshaw, H.D.; Schemske, D.W. Allele substitution at a flower colour locus produces a pollinator shift in monkeyflowers. Nature 2003, 426, 176-178. [CrossRef]

135. Handelman, C.; Kohn, J.R. Hummingbird color preference within a natural hybrid population of Mimulus aurantiacus (Phrymaceae). Plant Species Biol. 2014, 29, 65-72. [CrossRef]

136. Giurfa, M.; Núñez, J.; Chittka, L.; Menzel, R. Colour preferences of flower-naive honeybees. J. Comp. Physiol. A 1995, 177, 247-259. [CrossRef]

137. Hill, P.S.M.; Wells, P.H.; Wells, H. Spontaneous flower constancy and learning in honey bees as a function of colour. Anim. Behav. 1997, 54, 615-627. [CrossRef]

138. Chen, Z.; Liu, C.Q.; Sun, H.; Niu, Y. The ultraviolet colour component enhances the attractiveness of red flowers of a bee-pollinated plant. J. Plant Ecol. 2020, 13, 354-360. [CrossRef]

139. Alcorn, K.; Whitney, H.; Glover, B. Flower movement increases pollinator preference for flowers with better grip. Funct. Ecol. 2012, 26, 941-947. [CrossRef]

140. Whitney, H.M.; Poetes, R.; Steiner, U.; Chittka, L.; Glover, B.J. Determining the contribution of epidermal cell shape to petal wettability using isogenic antirrhinum lines. PLoS ONE 2011, 6, e17576. [CrossRef]

141. Giuliani, C.; Giovanetti, M.; Lupi, D.; Mesiano, M.P.; Barilli, R.; Ascrizzi, R.; Flamini, G.; Fico, G. Tools to tie: Flower characteristics, voc emission profile, and glandular trichomes of two mexican salvia species to attract bees. Plants 2020, 9, 1645. [CrossRef]

142. Solís-Montero, L.; Cáceres-García, S.; Alavez-Rosas, D.; García-Crisóstomo, J.F.; Vega-Polanco, M.; Grajales-Conesa, J.; Cruz-López, L. Pollinator preferences for floral volatiles emitted by dimorphic anthers of a buzz-pollinated herb. J. Chem. Ecol. 2018, 44, 1058-1067. [CrossRef]

143. Makino, T.T.; Ohashi, K.; Sakai, S. How do floral display size and the density of surrounding flowers influence the likelihood of bumble bee revisitation to a plant? Funct. Ecol. 2007, 21, 87-95. [CrossRef]

144. Shrestha, M.; Garcia, J.E.; Burd, M.; Dyer, A.G. Australian native flower colours: Does nectar reward drive bee pollinator flower preferences? PLoS ONE 2020, 15, e0226469. [CrossRef]

145. Perera, R.A.S.N.; Karunaratne, W.A.I.P. Floral visits of the wild bee, lithurgus atratus, impact yield and seed germinability of okra, abelmoschus esculentus, in sri lanka. Pollinat. Ecol. 2019, 25, 1-6. [CrossRef]

146. Mallinger, R.E.; Prasifka, J.R. Bee visitation rates to cultivated sunflowers increase with the amount and accessibility of nectar sugars. J. Appl. Entomol. 2017, 141, 561-573. [CrossRef]

147. Rowe, L.; Gibson, D.; Bahlai, C.A.; Gibbs, J.; Landis, D.A.; Isaacs, R. Flower traits associated with the visitation patterns of bees. Oecologia 2020, 193, 511-522. [CrossRef] 
148. Robertson, A.W.; Mountjoy, C.; Faulkner, B.E.; Roberts, M.V.; Macnair, M.R. Bumble bee selection of Mimulus guttatus flowers: The effects of pollen quality and reward depletion. Ecology 1999, 80, 2594-2606. [CrossRef]

149. Mallinger, R.E.; Franco, J.G.; Prischmann-Voldseth, D.A.; Prasifka, J.R. Annual cover crops for managed and wild bees: Optimal plant mixtures depend on pollinator enhancement goals. Agric. Ecosyst. Environ. 2019, 273, 107-116. [CrossRef]

150. Urbanowicz, C.; Muñiz, P.A.; McArt, S.H. Honey bees and wild pollinators differ in their preference for and use of introduced floral resources. Ecol. Evol. 2020, 10, 6741-6751. [CrossRef]

151. Ropars, L.; Dajoz, I.; Fontaine, C.; Muratet, A.; Geslin, B. Wild pollinator activity negatively related to honey bee colony densities in urban context. PLoS ONE 2019, 14, e0222316. [CrossRef]

152. Pritchard, D.J.; Vallejo-Marín, M. Floral vibrations by buzz-pollinating bees achieve higher frequency, velocity and acceleration than flight and defence vibrations. J. Exp. Biol. 2020, 223, jeb220541. [CrossRef]

153. Pritchard, D.J.; Vallejo-marín, M. Quick guide Buzz pollination 1l. Curr. Biol. 2020, 30, R858-R860. [CrossRef]

154. De Luca, P.A.; Cox, D.A.; Vallejo-marín, M. Comparison of pollination and defensive buzzes in bumblebees indicates speciesspecific and context-dependent vibrations. Naturwissenschaften 2014, 101, 331-338. [CrossRef]

155. Vallejo-Marín, M. Buzz pollination: Studying bee vibrations on flowers. New Phytol. 2019, 224, 1068-1074. [CrossRef]

156. Russell, A.L.; Leonard, A.S.; Gillette, H.D.; Papaj, D.R. Concealed floral rewards and the role of experience in floral sonication by bees. Anim. Behav. 2016, 120, 83-91. [CrossRef]

157. Corbet, S.A.; Huang, S.-Q. Buzz pollination in eight bumblebee-pollinated Pedicularis species: Does it involve vibration-induced triboelectric charging of pollen grains? Ann. Bot. 2014, 114, 1665-1674. [CrossRef] [PubMed]

158. Cardinal, S.; Buchmann, S.L.; Russell, A.L. The evolution of floral sonication, a pollen foraging behavior used by bees (Anthophila). Evolution 2018, 72, 590-600. [CrossRef]

159. Wcislo, W.T.; Tierney, S.M. Behavioural environments and niche construction: The evolution of dim-light foraging in bees. Biol. Rev. 2009, 84, 19-37. [CrossRef]

160. Ma, W.; Li, X.; Shen, J.; Du, Y.; Xu, K.; Jiang, Y. Transcriptomic analysis reveals Apis mellifera adaptations to high temperature and high humidity. Ecotoxicol. Environ. Saf. 2019, 184, 109599. [CrossRef]

161. Dolezal, A.G.; Toth, A.L. Feedbacks between nutrition and disease in honey bee health. Curr. Opin. Insect Sci. 2018, 26, 114-119. [CrossRef] [PubMed]

162. Huang, Z.Y.; Giray, T. Factors affecting pollinators and pollination. Psyche 2012, 2012. [CrossRef]

163. Christopher Brown, J.; Albrecht, C. The effect of tropical deforestation on stingless bees of the genus Melipona (Insecta: Hymenoptera: Apidae: Meliponini) in central Rondonia, Brazil. J. Biogeogr. 2001, 28, 623-634. [CrossRef]

164. Yang, D.; Xu, X.; Zhao, H.; Yang, S.; Wang, X.; Zhao, D.; Diao, Q.; Hou, C. Diverse factors affecting efficiency of RNAi in honey bee viruses. Front. Genet. 2018, 9, 384-392. [CrossRef] [PubMed]

165. O'Neal, S.T.; Swale, D.R.; Anderson, T.D. ATP-sensitive inwardly rectifying potassium channel regulation of viral infections in honey bees. Sci. Rep. 2017, 7, 8668-8676. [CrossRef]

166. van Engelsdorp, D.; Evans, J.D.; Saegerman, C.; Mullin, C.; Haubruge, E.; Nguyen, B.K.; Frazier, M.; Frazier, J.; Cox-Foster, D.; Chen, Y.; et al. Colony collapse disorder: A descriptive study. PLoS ONE 2009, 4, e6481. [CrossRef]

167. Van Dooremalen, C.; van Langevelde, F. Can colony size of honeybees (Apis mellifera) be used as predictor for colony losses due to varroa destructor during winter? Agriculture1 2021, 11, 529. [CrossRef]

168. Snow, J.W.; Ceylan Koydemir, H.; Karinca, D.K.; Liang, K.; Tseng, D.; Ozcan, A. Rapid imaging, detection, and quantification of Nosema ceranae spores in honey bees using mobile phone-based fluorescence microscopy. Lab Chip 2019, 19, 789-797. [CrossRef] [PubMed]

169. Conroy, T.J.; Palmer-Young, E.C.; Irwin, R.E.; Adler, L.S. Food limitation affects parasite load and survival of Bombus impatiens (Hymenoptera: Apidae) infected with Crithidia (Trypanosomatida: Trypanosomatidae). Environ. Entomol. 2016, 45, 1212-1219. [CrossRef]

170. Han, W.; Yang, Y.; Gao, J.; Zhao, D.; Ren, C.; Wang, S.; Zhao, S.; Zhong, Y. Chronic toxicity and biochemical response of Apis cerana cerana (Hymenoptera: Apidae) exposed to acetamiprid and propiconazole alone or combined. Ecotoxicology 2019, 28, 399-411. [CrossRef] [PubMed]

171. Christen, V.; Kunz, P.Y.; Fent, K. Endocrine disruption and chronic effects of plant protection products in bees: Can we better protect our pollinators? Environ. Pollut. 2018, 243, 1588-1601. [CrossRef] [PubMed]

172. Arce, A.N.; Ramos Rodrigues, A.; Yu, J.; Colgan, T.J.; Wurm, Y.; Gill, R.J. Foraging bumblebees acquire a preference for neonicotinoid-treated food with prolonged exposure. Proceedings. Biol. Sci. 2018, 285, 8-11. [CrossRef] [PubMed]

173. Woodcock, B.A.; Isaac, N.J.B.; Bullock, J.M.; Roy, D.B.; Garthwaite, D.G.; Crowe, A.; Pywell, R.F. Impacts of neonicotinoid use on long-term population changes in wild bees in England. Nat. Commun. 2016, 7, 12459. [CrossRef]

174. Jiang, J.; Ma, D.; Zou, N.; Yu, X.; Zhang, Z.; Liu, F.; Mu, W. Concentrations of Imidacloprid and Thiamethoxam in Pollen, Nectar and Leaves from seed-Dressed Cotton Crops and their Potential Risk to Honeybees (Apis mellifera L.); Elsevier Ltd.: Amsterdam, The Netherlands, 2018; Volume 201, ISBN 8605388242.

175. Tosi, S.; Nieh, J.C.; Sgolastra, F.; Cabbri, R.; Medrzycki, P. Neonicotinoid pesticides and nutritional stress synergistically reduce survival in honey bees. Proc. R. Soc. B Biol. Sci. 2017, 284, 20171711-20171719. [CrossRef]

176. Tomé, H.V.V.; Ramos, G.S.; Araújo, M.F.; Santana, W.C.; Santos, G.R.; Guedes, R.N.C.; Maciel, C.D.; Newland, P.L.; Oliveira, E.E. Agrochemical synergism imposes higher risk to neotropical bees than to honeybees. R. Soc. Open Sci. 2017, 4, 160866. [CrossRef] 
177. Vanegas, M. The silent beehive: How the decline of honey bee populations shifted the environmental protection agency's pesticide policy towards pollinators. Ecol. Law Q. 2017, 44, 311-342.

178. Rortais, A.; Arnold, G.; Dorne, J.L.; More, S.J.; Sperandio, G.; Streissl, F.; Szentes, C.; Verdonck, F. Risk assessment of pesticides and other stressors in bees: Principles, data gaps and perspectives from the European Food Safety Authority. Sci. Total Environ. 2017, 587-588, 524-537. [CrossRef]

179. Tschoeke, P.H.; Oliveira, E.E.; Dalcin, M.S.; Silveira-Tschoeke, M.C.A.C.; Sarmento, R.A.; Santos, G.R. Botanical and synthetic pesticides alter the flower visitation rates of pollinator bees in Neotropical melon fields. Environ. Pollut. 2019, 251, 591-599. [CrossRef]

180. Liporoni, R.; Cordeiro, G.D.; Prado, P.I.; Schlindwein, C.; Warrant, E.J.; Alves-dos-Santos, I. Light intensity regulates flower visitation in Neotropical nocturnal bees. Sci. Rep. 2020, 10, 1-11. [CrossRef]

181. Kenefic, N.E.; González, P.L.; Theodorou, P.; Cardona, E. Disentangling the effects of local resources, landscape heterogeneity and climatic seasonality on bee diversity and plant-Pollinator networks in tropical highlands. Oecologia 2020, 194, 333-344. [CrossRef]

182. Grassl, J.; Holt, S.; Cremen, N.; Peso, M.; Hahne, D.; Baer, B. Synergistic effects of pathogen and pesticide exposure on honey bee (Apis mellifera) survival and immunity. J. Invertebr. Pathol. 2018, 159, 78-86. [CrossRef]

183. Dalsgaard, B. Land-use and climate impacts on plant-pollinator interactions and pollination services. Diversity 2020, $12,168$. [CrossRef]

184. Jacques, A.; Laurent, M.; Consortium, E.; Ribière-Chabert, M.; Saussac, M.; Bougeard, S.; Budge, G.E.; Hendrikx, P.; Chauzat, M.-P. A pan-European epidemiological study reveals honey bee colony survival depends on beekeeper education and disease control. PLoS ONE 2017, 12, e0172591. [CrossRef]

185. Cook, D.F.; Voss, S.C.; Finch, J.T.D.; Rader, R.C.; Cook, J.M.; Spurr, C.J. The role of flies as pollinators of horticultural crops: An Australian case study with worldwide relevance. Insects 2020, 11, 341. [CrossRef]

186. Larson, B.M.H.; Kevan, P.G.; Inouye, D.W. Flies and flowers: Taxonomic diversity of anthophiles and pollinators. Can. Entomol. 2001, 133, 439-465. [CrossRef]

187. Hodgkiss, D.; Brown, M.J.F.; Fountain, M.T. Syrphine hoverflies are effective pollinators of commercial strawberry. J. Pollinat. Ecol. 2018, 22, 55-66. [CrossRef]

188. Jauker, F.; Wolters, V. Hover flies are efficient pollinators of oilseed rape. Oecologia 2008, 156, 819-823. [CrossRef]

189. Howlett, B.G.; Gee, M. The potential management of the drone fly (Eristalis tenax) as a crop pollinator in New Zealand. N. Z. Plant Prot. 2019, 72, 221-230. [CrossRef]

190. Schittenhelm, S.; Gladis, T.; Rao, V.R. Efficiency of various insects in germplasm regeneration of carrot, onion and turnip rape accessions. Plant Breed. 1997, 116, 369-375. [CrossRef]

191. Jarlan, A.; De Oliveira, D.; Gingras, J. Pollination of sweet pepper (Capsicum annuum L.) in green-house by the syrphid fly Eristalis tenax (L.). Acta Hortic. 1997, 437, 335-339. [CrossRef]

192. Barbattini, R.; Greatti, M.; Zandigiacomo, P.; Costa, G.; Testolin, R.; Vizzotto, G. Insect pollinators of kiwifruit and their role in crop pollination. In Proceedings of the Atti XVII Congresso Nazionale Italiano di Entomologia, Udine, Italy, 13-18 June 1994; pp. 13-18.

193. Hahn, M.; Brühl, C.A. The secret pollinators: An overview of moth pollination with a focus on Europe and North America. Arthropod. Plant. Interact. 2016, 10, 21-28. [CrossRef]

194. Santos, R.d.S.; Milfont, M.d.O.; Silva, M.M.; Carneiro, L.T.; Castro, C.C. Butterflies provide pollination services to macadamia in northeastern Brazil. Sci. Hortic. 2020, 259, 108818-108825. [CrossRef]

195. Martins, D.J. Butterfly pollination of the dryland wildflower gloriosa minor. J. East African Nat. Hist. 2014, 103, 25-30. [CrossRef]

196. Cruden, R.W.; Hermann-parker, S.M. Butterfly pollination of Caesalpinia pulcherrima, with observations on a psychophilous syndrome. Br. Ecol. Soc. 1979, 67, 155-168. [CrossRef]

197. Pinto, C.E.; Oliveira, R.; Schlindwein, C. Do consecutive flower visits within a crown diminish fruit set in mass-flowering Hancornia speciosa (Apocynaceae)? Plant Biol. 2008, 10, 408-412. [CrossRef]

198. Barrios, B.; Koptur, S. Floral biology and breeding system of Angadenia berteroi (Apocynaceae): Why do flowers of the pineland golden trumpet produce few fruits? Int. J. Plant Sci. 2011, 172, 378-385. [CrossRef]

199. Gann, G.D.; Woodmansee, S.W.; Bradley, K.A. Conserving rare plants in locally-protected urban forest fragments: A case study from Miami-Dade County, Florida. Urban For. Urban Greening. 2020, 20, 1-11.

200. Macgregor, C.J.; Pocock, M.J.O.; Fox, R.; Evans, D.M. Pollination by nocturnal Lepidoptera, and the effects of light pollution: A review. Ecol. Entomol. 2015, 40, 187-198. [CrossRef]

201. Ricketts, T.H.; Regetz, J.; Steffan-Dewenter, I.; Cunningham, S.A.; Kremen, C.; Bogdanski, A.; Gemmill-Herren, B.; Greenleaf, S.S.; Klein, A.M.; Mayfield, M.M.; et al. Landscape effects on crop pollination services: Are there general patterns? Ecol. Lett. 2008, 11, 499-515. [CrossRef]

202. Power, A.G. Ecosystem services and agriculture: Tradeoffs and synergies. Philos. Trans. R. Soc. B Biol. Sci. 2010, 365, $2959-2971$. [CrossRef]

203. Alarcón, R.; Davidowitz, G.; Bronstein, J.L. Nectar usage in a southern Arizona hawkmoth community. Ecol. Entomol. 2008, 33, 503-509. [CrossRef] 
204. Devoto, M.; Bailey, S.; Memmott, J. The "night shift": Nocturnal pollen-transport networks in a boreal pine forest. Ecol. Entomol. 2011, 36, 25-35. [CrossRef]

205. Sime, K.R.; Baldwin, I.T. Predominantly self-fertilizing native tobacco. BMC Ecol. 2003, 3, 6-14. [CrossRef]

206. Armstrong, J.E.; Irvine, A.K. Floral biology of Myristica insipida (Myristicaceae), a distinctive beetle pollination syndrome. Am. J. Bot. 1989, 76, 86-94. [CrossRef]

207. Bernhardt, P. Convergent evolution and adaptive radiation of beetle-pollinated angiosperms. Pl Syst. Evol. 2000, 222, 293-320. [CrossRef]

208. Dieringer, G.; Cabrera, R.L.; Lara, M.; Loya, L.; Reyes, P.; Journal, I. Beetle pollination and floral thermogenicity in Magnolia tamaulipana (Magnoliaceae). Int. J. Plant Sci. 1999, 160, 64-71. [CrossRef]

209. Mayer, C.; Soka, G.; Picker, M. The importance of monkey beetle (Scarabaeidae: Hopliini) pollination for Aizoaceae and Asteraceae in grazed and ungrazed areas at Paulshoek, Succulent Karoo, South Africa. J. Insect Conserv. 2006, 10, 323-333. [CrossRef]

210. Devy, M.S.; Davidar, P. Pollination systems of trees in Karachi, a mid-elevation wet evergreen forest in Western Ghats, India. Am. J. Bot. 2003, 90, 650-657. [CrossRef] [PubMed]

211. Momose, K.; Yumoto, T.; Nagamitsu, T.; Kato, M.; Nagamasu, H.; Sakai, S.; Harrison, R.D.; Itioka, T.; Hamid, A.A.; Inoue, T. Pollination biology in a lowland dipterocarp forest in Sarawak, Malaysia. I. Characteristics of the plant-pollinator community in a lowland dipterocarp forest. Am. J. Bot. 1998, 85, 1477-1501. [CrossRef]

212. Colville, J.; Picker, M.D.; Cowling, R.M. Species turnover of monkey beetles (Scarabaeidae: Hopliini) along environmental and disturbance gradients in the Namaqualand region of the succulent Karoo, South Africa. Biodivers. Conserv. 2002, 11, 243-264. [CrossRef]

213. Van Kleunen, M.; Nänni, I.; Donaldson, J.S.; Manning, J.C. The role of beetle marks and flower colour on visitation by monkey beetles (Hopliini) in the greater c \ape Floral Region, South Africa. Ann. Bot. 2007, 100, 1483-1489. [CrossRef]

214. Sayers, T.D.J.; Steinbauer, M.J.; Miller, R.E. Visitor or vector? The extent of rove beetle (Coleoptera: Staphylinidae) pollination and floral interactions. Arthropod. Plant. Interact. 2019, 13, 685-701. [CrossRef]

215. Suetsugu, K. Social wasps, crickets and cockroaches contribute to pollination of the holoparasitic plant Mitrastemon yamamotoi (Mitrastemonaceae) in southern Japan. Plant Biol. 2019, 21, 176-182. [CrossRef]

216. Ananthakrishnan, T.N. Thrips and pollination biology. Curr. Sci. 1982, 51, 168-172.

217. Infante, F.; Ortíz, J.A.; Solis-Montero, L.; Mound, L.A.; Vega, F.E. Thrips (Thysanoptera) of coffee flowers. Ann. Entomol. Soc. Am. 2017, 110, 329-336. [CrossRef]

218. Resende, J.J.; de M. Santos, G.M.; Bichara Filho, C.C.; Gimenes, M. Atividade diária de busca de recursos pela vespa social Polybia occidentalis occidentalis (Olivier, 1791) (Hymenoptera, Vespidae). Rev. Bras. Zoociências 2001, 3, 105-115.

219. Beggs, J. The ecological consequences of social wasps (Vespula spp.) invading an ecosystem that has an abundant carbohydrate resource. Biol. Conserv. 2001, 99, 17-28. [CrossRef]

220. Schremmer, F. Wespen und Hornissen; Ziemsen: Wittenberg Lutherstadt, Germany, 1962.

221. Brodmann, J.; Twele, R.; Francke, W.; Hölzler, G.; Zhang, Q.H.; Ayasse, M. Orchids mimic green-leaf volatiles to attract prey-hunting wasps for pollination. Curr. Biol. 2008, 18, 740-744. [CrossRef] [PubMed]

222. Jakubska-Busse, A.; Przado, D.; Steininger, M.; Anioll-Kwiatkowska, J.; Kadej, M. Why do pollinators become "sluggish"? Nectar chemical constituents from Epipactis helleborine (L.) crantz (Orchidaceae). Appl. Ecol. Environ. Res. 2005, 3, 29-38. [CrossRef] 